\title{
A Private Mystery: Looking at Philippe de Champaigne's Annunciation for the Hôtel de Chavigny
}

\author{
Mette Birkedal Bruun
}

Mysteries elude immediate access. The core meaning of the Greek word $\mu v \sigma \tau$ ṕpıv (mystérion) is something that is hidden, and hence accessible only through some form of initiation or revelation. ${ }^{1}$ The key Christian mysteries concern the meeting between Heaven and Earth in the Incarnation and the soteriological grace wielded in Christ's Passion and Resurrection as well as in the sacraments of the Church. Visual representations of the Christian mysteries strive to capture and convey what is hidden and to express the ineffable in a congruent way. Such representations are produced in historical contexts, and in their aspiration to represent motifs that transcend time and space and indeed embrace time and space, they are marked through and through by their own Sitz-im-Leben. Also, the viewers' perceptions of such representations are embedded in a historical context. It is the key assumption of this chapter that early modern visual representations of mysteries are seen by human beings whose gaze and understanding are shaped by historical factors. ${ }^{2}$

We shall approach one such historical gaze. It belongs to a figure who navigated a particular space; who was born into a particular age and class; endowed with a particular set of experiences and aspirations; and informed by a particular devotional horizon. The figure whose gaze we shall approach is Léon Bouthillier, Comte de Chavigny (1608-1652). The mystery in focus is the Annunciation, and the visual representation is the Annunciation painted

1 See Strong's Exhaustive Concordance, “3466. mustérion" https://biblehub.com/str/greek/3466.

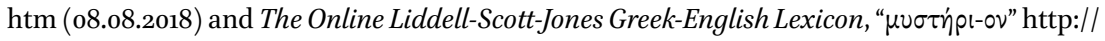
stephanus.tlg.uci.edu.ep.fjernadgang.kb.dk/lsj/\#eid=71742\&context=lsj\&action=from-search (08.08.2018).

2 The research presented in this chapter is associated with the Danish National Research Foundation Centre for Privacy Studies (PRIVACY), housed at the Faculty of Theology, University of Copenhagen (DNRF 138). I thank each of my PRIVACY colleagues for having inspired the insights presented here. I am particularly grateful to Lars Nørgaard. Thanks are due also to Anne Régent-Susini, Walter Melion, and Lee Palmer Wandel, as well as to the other participants of the conference Quid est sacramentum for stimulating questions.

(C) METTE BIRKEDAL BRUUN, 2020 | DOI:10.1163/9789004408944_021

This is an open access chapter distributed under the terms of the CC-BY-NC-ND 4.Q License. Bruun - 9789004408944 
around 1643 by Philippe de Champaigne (1602-1674) for the count's private chapel in the Hôtel de Chavigny, located in what is now the rue de Sévigné in the Marais.

First, I sketch some historical contours. Chavigny's political career is not central in this context, but we shall linger over his devotional profile. This profile is elusive, for archives are scattered, ${ }^{3}$ and sources are biased. The greatest methodological challenge is, however, how to evaluate critically issues to do with belief and sincerity, since, judging from contemporary assessments of the count's faith or lack thereof, Chavigny spent his adult life as an unresolved convert. Positioning this dimly lit historical figure at the centre of our study, insistently reminds us that this specific Annunciation, if it is properly to be appreciated, must not be construed in black-and-white, and also encourages us to examine its particularities, situating it in relation to a particular building, a particular set of texts, and a particular human trajectory. On this basis, we shall try to determine how Chavigny was taught to view Champaigne's picture, the gaze he brought to bear when looking at the encounter between Gabriel and Mary, in his private chapel in the Hôtel de Chavigny.

Typical of his age, class, and kin, the Comte de Chavigny strove to excel in politics and religion [Fig. 20.1]. Many contemporaries deemed him wanting in both respects, finding that his ambition wrecked his political career while worldly entanglement got in the way of true conversion. Chavigny was the only child of Marie de Bragelogne (1590-1673) and Claude Bouthillier (1581-1652), secretary of state and surintendant des finances. ${ }^{4}$ His birth into the Bouthillier clan came with links to Richelieu, ${ }^{5}$ the Queen Mother, and Gaston d'Orléans,

3 See Le Guillou Y., Les Bouthillier, de l'avocat au surintendant (ca 1540-1652): histoire d'une ascension sociale et formation d'une fortune, Thèse pour le diplôme d'archiviste paléographe (École nationale des chartes: 1997) 9-12.

4 From 1635, Léon Bouthillier was known as 'Chavigny' to distinguish him from his father. For the rumours that Chavigny was Richelieu's offspring, see, e.g., Brienne L.-H. de Loménie, comte de, Mémoires inédits de Louis-Henri de Loménie, comte de Brienne, secrétaire d'état sous Louis XIV publiés sur les Manuscrits autographs, ed. F. Barrière, 2 vols. (Paris - Leipzig: 1828) I 278; and Le Guillou, Les Bouthillier 148-154.

5 Chavigny's father and three uncles were Richelieu's créatures; they consolidated their careers in the early 1620 s in step with his ascent; see Ranum O., Richelieu and the Councillors of Louis XIII: A Study of the Secretaries of State and Superintendents of Finance in the Ministry of Richelieu 1635-1642 (Oxford: 1963) 28; and Mousnier R., Les Institutions de France sous la monarchie absolue, 1598-1789, 2 vols. (Paris: 1974-1980) II 150-151. The First Minister relied on 


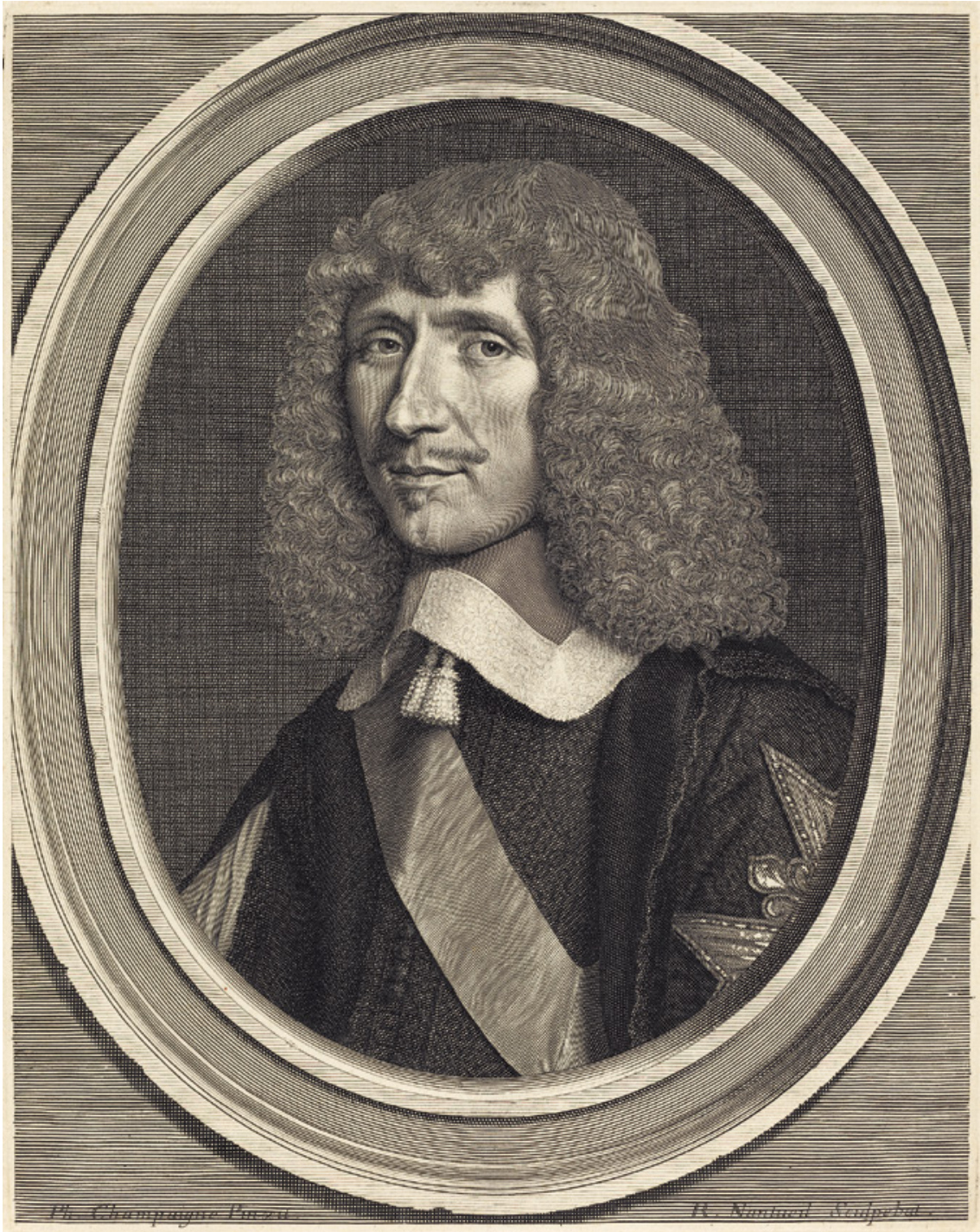

FIGURE 20.1 Robert Nanteuil, Léon Bouthillier, comte de Chavigny, ca. 1651. Engraving, sheet: $31.6 \times 24.8 \mathrm{~cm}$. New York, Metropolitan Museum of Art. Gift of Georgiana W. Sargent, in memory of John Osborne Sargent, 1924 
with connections to the Oratorians and to Port-Royal, ${ }^{6}$ as well as to circles graced by diplomats, clergy, and cultural icons. ${ }^{7}$ Chavigny was a member of the Queen Mother's council (from 1629) and secrétaire d'état, with responsibility for foreign affairs (from 1632 ). ${ }^{8}$ With Richelieu's assistance, he became Gaston d'Orléans's counsellor in 1634 and his chancellor in $1635,{ }^{9}$ and in 1638 he took up the position of governor of Vincennes. Chavigny was a member of the regency council that Louis XIII (1601-1643) constituted in his will to assist Anne d'Autriche (1601-1666) in ruling for her infant son. When the king died in May 1643, however, Mazarin overturned the plan, and through the last decade of Chavigny's life, his career suffered from ongoing feuds with the Cardinal and an oscillation between favour in Paris and exile to his rural estates, culminating in a wavering course during the Fronde. ${ }^{10}$ Condé's ensuing accusations of treason - and a harsh diet - allegedly took their toll to such an extent that Chavigny died at the age of forty-four. ${ }^{11}$

Claude for information about the king, on Denis (1585-1650), the Queen Mother's secretary, for information about her, and on Victor (1596-1670), archbishop of Tours, for information about the clergy. The relationship between Richelieu and Chavigny harked back to his paternal grandfather, Denis Bouthillier, who had been a clerk of Richelieu's maternal grandfather. After his father's death in 1590, Richelieu was raised in Denis Bouthillier's home and treated like one of his children. On Chavigny's aunts and uncles, see Ranum, Richelieu and the Councillors $3^{2-} 33$; and Le Guillou, Les Bouthillier 128.

6 Goldmann uses the family as a key case for the widely contested hypothesis that the noblesse de robe were the backbone of Jansenism; see Goldmann L., Le Dieu caché: étude sur la vision tragique dans les Pensées de Pascal et dans le théâtre de Racine (Paris: 1959; reprint ed., 1975) 124-128.

7 Lesaulnier J., “Chavigny, Léon Bouthillier, comte de”, in Lesaulnier J. - McKenna A. (eds.), Dictionnaire de Port-Royal (Paris: 2004) 256-258; and Mayer D., "Madame du PlessisGuénégaud, née Elisabeth de Choiseul (1610-1677) I-II", XVIIe siècle 155 (1987) 173-186; $15^{6}$ (1987) 313-327.

8 Le Guillou, Les Bouthillier 141. On Chavigny's career, see ibid. 156-157; Lesaulnier, "Chavigny" 256-258; and Josse A.-C., "Introduction", in Josse A.-C. (ed.), Lettres d'Antoine Singlin (Paris: 2004) 9-145, esp. 92-95.

9 See Saint-Simon, Louis de Rouvroy, duc de, Mémoires, ed. Y. Coirault, 8 vols. (Paris: 1983-1988) I 70. On the relationship between Chavigny and Gaston, see Scott P., Le Gouvernement présent, ou éloge de son Eminence, satyre ou la Miliade (London: 2010) 141; and Ranum, Richelieu and the Councillors $85^{-87}$.

10 Lesaulner, "Chavigny" 258. For a contemporary and biased account of this process, see Retz Jean-François Paul de, Cardinal de Gondi, Les Contre temps du Sieur de Chavigny, premier ministre de M. le Prince (n.p.: 1652).

11 Motteville F. B. de, Mémoires de Mme de Motteville, nouvelle édition, ed. M. F. Rieaux, 4 vols. (Paris: 1896) IV 31-32; Rapin R., Mémoires du P. René Rapin de la compagnie de Jésus sur l'église, la ville et le jansénisme, ed. L. Aubineau, 3 vols. (Paris: 1865) I 466-470; and Hermant G., Mémoires (1630-1663), ed. A. Gazier, 6 vols. (Paris: 1905-1910) I 670-697. 
Chavigny's religious horizon was shaped by his familial background. His father had bonds to Jean Duvergier de Hauranne, abbé de Saint-Cyran (15811643), ${ }^{12}$ and cultivated connections with Robert Arnauld d'Andilly (1589-1674), whose memoirs attest to their friendship, ${ }^{13}$ and whose letters refer with warmth to the beauty of Claude Bouthillier's estate at Pont-sur-Seine and the repose that D'Andilly hopes to enjoy there. ${ }^{14}$ D'Andilly also praises Chavigny's mother for her constant affection, ${ }^{15}$ but indications regarding Marie de Bragelogne's religious piety date above all from after Chavigny's death, and her possible devotional influence on her son is not easily determined. ${ }^{16}$ Most important in our context is Chavigny's uncle Sébastien Bouthillier (ca. 1580-1625), bishop of Aire and close friend of Saint-Cyran. ${ }^{17}$ On his deathbed, Sébastien asked SaintCyran to supervise his seventeen-year-old nephew, and two years later, the year of Chavigny's marriage to Anne Phélypeaux (1613-1694), ${ }^{18}$ Saint-Cyran's instructions appeared as Le cour nouveau, a treatise on conversion with the subtitle "Exercice pour une personne engagée dans le monde, \& dans le mariage, nouvellement convertie à Dieu" ("Exercise for someone engaged in the

On Chavigny's strict diet, maintained in order to stay slender, see, among other sources, Brienne, Mémoires inédits 422, describing his emaciated appearance.

12 Orcibal J., Les Origines du Jansénisme, vol. 2: Jean Duvergier de Hauranne: Abbé de SaintCyran et son Temps (Louvain - Paris: 1947) 380.

13 See D’Andilly R. A., Mémoires, suivis de Antoine Arnauld, dit l'abbé Arnauld: Mémoires, ed. R. Pouzet (Paris: 2008) 255 .

14 Letter of 28 September 1642 from D'Andilly to Claude Bouthillier; see Lettre 232 in Lettres de Monsievr Arnavld d'Andilly (Paris, La veuve Jean Camusat - Pierre le Petit: 1645) 386387, esp. 387 .

15 D'Andilly, Mémoires, 256; on this friendship, see also Rancé A.-J. Bouthillier de, Correspondance, ed. A.-J. Krailsheimer, 4 vols. (Paris - Cîteaux: 1993) I 125.

16 D'Andilly sent to Marie Bragelogne the twelfth, thirteenth, and fourteenth Lettres provinciales by Pascal on 7 December 1656, and the sixteenth on 23 December 1656; cf. D'Andilly R. A., Arnauld d'Andilly Défenseur de Port-Royal (1654-1659): sa correspondence inédite avec la Cour, ed. P. Jansen (Paris: 1973) 113-114. See also D'Andilly, Mémoires 256, note 1. In Pascal's sixteenth provincial letter, Mme Bouthillier could read about the turmoil following her son's death (see below); see Pascal B., Les Provinciales, ed. L. Cognet (Paris: 1965) 299. Chavigny's mother seems to have offered religious inspiration to her husband's nephew, the Trappist reformer Armand-Jean de Rancé (1626-1700) during his conversion; see, among other sources, Rancé's letters written from Pont-sur-Seine to D'Andilly on 16 June 1659 and to Louise Rogier on 1 June 166o; Rancé, Correspondance I 124-125 and 149-150. Rancé credits Marie Bragelogne with having introduced him to D'Andilly; see his letter of 19 June 1673 to D'Andilly; Rancé, Correspondance I 561.

17 On this friendship, see Lancelot Claude, Mémoires touchant la vie de Monsieur de S. Cyran, 2 vols. (Cologne, La Compagnie: 1738) I 281-282 and II 267; and D'Andilly, Mémoires 213214. See also Orcibal J., Saint-Cyran et le jansénisme (Paris: 1961) 9-10; and Orcibal, Les Origines II 223-227, 381, 643 .

18 Le Guillou, Les Bouthillier 282-288. 
world and in marriage, recently converted to God"). ${ }^{19}$ A decade later, in 1638 , the two men found themselves on opposite sides, with Saint-Cyran imprisoned at the Château de Vincennes, in Chavigny's charge. ${ }^{20}$ In an attempt to ameliorate Saint-Cyran's difficult situation, Chavigny urged him to recant in writing on a number of controversial issues, including his conviction that contrition, and not merely attrition, is necessary for salvation. ${ }^{21}$ According to Hermant, the recantation, which Saint-Cyran afterwards regretted, ${ }^{22}$ was fruitless at the time, but eventually led to Saint-Cyran's release. ${ }^{23}$ After a brief period under the spiritual guidance of Charles de Condren (1588-1641), the second superior of the Oratory and confessor of Gaston d'Orléans, ${ }^{24}$ Chavigny turned to Saint-Cyran's successor as director at Port-Royal, Antoine Singlin (1607-1664), and in his memoirs, René Rapin counts Chavigny among 'les importans du party', the key friends of Port-Royal, who sat beneath Singlin's pulpit: a group including prominent converts such as Louis Charles d'Albert, Duc de Luynes (1620-1690), ${ }^{25}$ Anne de Rohan-Guéméné $(1606-1685),{ }^{26}$ Roger du Plessis, Duc

19 Lancelot, Mémoires I 183. See also Josse, "Introduction" 93; Lesaulnier, "Chavigny" 258; and Orcibal, Les Origines II 381. Le cœur nouveau was printed in the Théologie familière (1637) and was curricular reading for the convent school at Port-Royal; cf. Pascal J., Règlement pour les enfants, in Blaise Pascal: CEuvres complètes, ed. J. Mesnard, 4 vols. (Paris: 1991) II 1155. Several versions appeared in 1643-1644, disseminating Saint-Cyran's instructions to a broader public; see Orcibal, Les Origines II 141.

20 It is difficult to assess the degree of personal contact up until then. Hermant, for one, is not aware of any close connection; see Hermant, Mémoires I 110.

21 Lancelot, Mémoires I 178-186; and Hermant, Mémoires I 110-114. Orcibal dates the meeting 23 or 24 August 1641; see Orcibal J., Les Origines du Jansénisme, vol. 3: Jean Duvergier de Hauranne: Abbé de Saint-Cyran et son Temps: Appendices, bibliographie et tables (Paris: 1948) 223.

22 Hermant, Mémoires II 297.

23 Hermant, Mémoires I 189; and Lancelot, Mémoires I 209-210. See also Mère Angélique's recognition of Chavigny's role in Saint-Cyran's release in her letter of October $165^{2}$ to Le Maistre; see Arnauld Angélique, Lettres de la Reverend Mere Marie Angelique Arnauld: abbesse et reformatrice, 3 vols. (Utrecht, Aux Depens de la Compagnie: 1742-1744) II 192 (Letter 482).

24 Lesaulnier, "Chavigny" 258.

25 Quantin J.-L., "Port-Royal et la haute noblesse: sur le cas du duc de Luynes (1620-169o)", in Grell C. - Ramière de Fortanier A. (eds.), Le second ordre: I'idéal nobiliaire. Hommage à Ellery Schalk (Paris: 1999) 109-131, esp. 116-129. See also Quantin J.-L., "Augustinisme, sexualité et direction de conscience: Port-Royal devant les tentations du duc de Luynes", Revue de l'histoire des religions 220.2 (2003) 167-207.

26 Orcibal J., Les Origines du Jansénisme, vol. 5: La spiritualité de Saint-Cyran (Paris: 1962) 275; and Hillman J., Female Piety and the Catholic Reformation in France (Abingdon: 2014) 57. 
de Liancourt (1609-1674), and Jeanne de Schomberg, Duchesse de Liancourt $(1600-1674),{ }^{27}$ as well as Guillaume Du Gué de Bagnols (1616-1657). ${ }^{28}$

Contemporary observers describe Chavigny's devotional trajectory as fluctuating. In his pamphlet on the count's political failure, Cardinal Retz (16131679) remarks that people hoped in vain that the count's association with Port-Royal might soften his proud and wild spirit; ${ }^{29}$ and Rapin adds in his memoirs that Chavigny's zeal for the doctrine of Port-Royal was soon devoured by his colossal ambition. ${ }^{30}$ Only Jean-Jacques Olier (1608-1657), in a description of Condren's charisma, avows that the count underwent conversion at the Oratorian's deathbed in 1641, and from that day was a 'modèle de piété à la cour' ('a model of piety at court'). ${ }^{31}$ However, in Mère Angélique Arnauld's view, the count converted only as he himself lay dying, ${ }^{32}$ and most observers seem to agree that up until that point Chavigny intermittently strove to be a dévot. A few hints of this striving stand out. The first is an enthusiastic and admiring letter sent from the nineteen-year old count to Saint-Cyran on 21 August 1627, the year of the publication of Le coeur nouveau. Chavigny envisages how the

27 Boileau Jean-Jacques, "Avertissement", in Liancourt Jeanne de Schomberg, duchesse de, Reglement donné par une dame de haute qualité a $M^{* * *}$ sa petite-fille Pour sa Conduite, \& pour celle de sa Maison, avec un autre Reglement que cette Dame avoit dressé pour ellemesme (Paris, Augustin Leguerrier: 1698) 1-101.

28 Rapin, Mémoires I 332. On Bagnols, see Neveu B., "Un ami de Port-Royal: Guillaume Du Gué de Bagnols (1616-1657)", Chroniques de Port-Royal 15-16 (1966) 45-92. On the converts drawn to Singlin, see also Fontaine Nicolas, Mémoires pour server a l'histoire de Port-Royal, 2 vols. (Utrecht, Aux dépens de la Compagnie: 1736) II 74-84 and Le Maistre Antoine, "Memoire de M. le Maitre touchant les personnes que Dieu auoit touchées d'un sentiment de pénitence \& qui s'étoient retirées en divers tems dans l'ancienne Abbaye de PortRoyal des champs", in Fontaine Nicolas, Mémoires pour server a l'histoire de Port-Royal, 2 vols. (Utrecht, Aux dépens de la Compagnie: 1736) I i-x. For other examples, see Josse, "Introduction" 69-76; see also Hillman, Female Piety 37-42. On Singlin's preaching, see the letters from Mère Angélique to Marie Louise Gonzaga of 4 July 1647 and 20 March 1648; Lettres I 337 and 363 (Letters 204 and 216). See also Josse, "Introduction" 81-85.

29 Retz, Les Contre temps 6.

30 Rapin, Mémoires I 439-441 (439).

31 Olier reports that Chavigny, one of the greats at Court, suddenly burst into tears and out of a true heart renounced the world and made a public profession of henceforth belonging to God. See Faillon E.-M. (ed.), Vie de M. Olier, fondateur du séminaire de S. Sulpice, 2 vols. (Paris: 1853) I 355. Lesaulnier takes Olier's statement at face value, giving 1641 as Chavigny's year of conversion; see Lesaulnier, "Chavigny" 257.

32 See Mère Angélique's letter to Le Maistre, of 11 October 1652, in Lettres II 195 (Letter 485): 'S'il se trouve de vraies conversions à la mort, comme il n'en faut pas douter, la sienne en sera une.' ('If there is such a thing as true deathbed conversions, of which we can have no doubt, his was one.'). 
director's vow to Sébastian Bouthillier obliges him to desire the young man's conversion, and he assures him of his own commitment to this endeavour,

Ie me console dans la promesse que vous mauez faite de nous venir voir à Ville-, ${ }^{33}$ en vous attendant auec vne tres-grande impatience [...]. Ie me prepare tous les iours à receuoir vos bonnes instructions, \& à vous faire gaigner en vn iour, ce que vous auez poursuiuy trois ans durant. ${ }^{34}[\ldots]$ Ie vous coniure donc par luy ${ }^{35}$ de me tenir parole, \& de me faire tousiours la faueur de m'aimer; i'esséray de la meriter, en recherchant les occasions de vous tesmoigner que ie suis, \& seray toute ma vie, Monsievr, Vostre treshumble, \& tres-obligé seruiteur, L.B. ${ }^{36}$

Awaiting you with great impatience, I take comfort in the promise that you have made to come and see us at Ville-. [...] I prepare myself each day to receive your good instruction and to make you achieve in one day what you have pursued for three years. [...] I thus implore you through him, to keep your word and always do me the favour of loving me; I shall strive to merit it, seeking occasions to show you that I am, and shall be for the rest of my life, Monsieur, your most humble and most faithful servant, L.B.

Grand-siècle conversions were ideally gradual, sometimes even hesitant, and sudden conversions such as Saint Paul's were considered miracles rather than models. ${ }^{37}$ Saint-Cyran himself described the ideal conversion as gradual and laborious, ${ }^{38}$ and we can only begin to imagine how the spiritual director reacted to Chavigny's eager wish for a swift effect.

33 That is, Villesavin, the castle of Chavigny's father-in-law, Jean Phélypeaux; see Orcibal, Les Origines vol. III, 211.

34 Sébastien Bouthillier died on 17 January 1625; see Orcibal, Les Origines vol. III, 207.

35 That is, Sébastien Bouthillier.

36 Extract of letter from Chavigny to Saint-Cyran of 21 August 1627. The extract is printed in Pinthereau François, Le Progrez dv Ianssenisme descovvert, a Monseignevr le Chancelier par le sievr de Preville (Avignon, Pierre Thomas: 1655) 104. The letter is identified in Orcibal, Les Origines III 160, where the page is, however, given as '14'.

37 Quantin J.-L., Le rigorisme chrétien (Paris: 2001) 26. On Paul's conversion, see below.

38 As heirs to Saint-Cyran's model, the directors of Port-Royal would encourage conversions based on prolonged reflection and mature decision. For two examples of a gradual conversion related to Port-Royal, see the later account of the conversion of Antoine Le Maistre (1608-1658), the first solitary of Port-Royal, and of his younger brother Simon Le Maistre de Séricourt (1611-1650), and its physical manifestation in a retreat still further into la solitude, in Anon., Histoire de l'origine des penitens et solitaires de Port-Royal des champs (Mons, Migeot le fils: 1733) 2-5. Cf. Jean-Jacques Boileau's account of the Duc de Liancourt, whose circuitous conversion was closely supervised by his wife; among other 
Some twenty years later, the count arrived at the gates of Port-Royal, on 9 March $1648,{ }^{39}$ together with the Duc de Liancourt and Singlin. The two courtiers came incognito, tearfully declaring that they wanted to withdraw from court and do penitence, and offering a substantial sum for the construction of a walled modest lodging adjacent to the Granges of Port-Royal de Champs. The offer was refused, and the two men left, allegedly much edified. ${ }^{40}$ Sincere tears were the sign of a penitential spirit, and Antoine Le Maistre, who reports the incident, seems content that the count's tears on this occasion were indeed genuine. ${ }^{41}$ Two years later, in the autumn or early winter of $1650,{ }^{42}$ we find Chavigny planning a religious retreat to a house in Saint-Jean des Troux owned by a friend of Port-Royal, Gué de Bagnols, which, Singlin assures him, is 'un vrai lieu de retraite' ('a veritable place of retreat'). ${ }^{43}$ Singlin conveys Bagnols's happiness at being able to assist Chavigny 'au dessin que vous avez de server Dieu' ('in your design to serve God'); offers to come and see him during his stay; and reports that all the brothers pray for Chavigny. ${ }^{44}$

means, she deployed horticulture and refined company at the Château de Liancourt, to draw the duke away from court; see Boileau, "Avertissement" 8-27. See also Neveu B., Sébastien-Joseph du Cambout de Pontchâteau (Paris: 1969) 15, and, for a description of the time, discipline, étapes, and efforts required to prepare the heart and soul for retreat, Beugnot B., "Loisir, retraite, solitude", in Fumaroli M. - Salazar P.-J. - Bury E. (eds.), Le loisir lettré à l'âge classique (Geneva: 1996) 173-195, esp. 180. See also Singlin's list of the rules by which a soul's true conversion is judged, and of the stages at which conversion is threatened; Singlin Antoine, "Pour le Jour des Rois: Troisième instruction", in Instructions chrestiennes sur les mysteres de Nostre Seigneur Jésus-Christ et sur les principales festes de l'année, 5 vols. (Paris, A. Pralard: 1692) I 287-297 (290-292).

39 Lesaulnier dates this event 1649; see "Chavigny" 258. Sainte-Beuve dates it 1647; see SainteBeuve C.-A., Port-Royal, 5 vols. (Paris: 1840-1859) II 256.

40 Le Maistre, "Memoire" v.

41 On the role of tears in the discretio spirituum, the examination of one's inner condition, including the sincerity of conversion, see McCormack J. W., "Discerning Tears in Early Modern Catholicism", in Aydelotte L. (ed.), A Mirror for Medieval and Early Modern Studies (Chicago: 2010) 49-59.

42 Singlin says that they can meet, but not on Christmas, when he is preaching at Port-Royal; see Singlin's letter to Chavigny of 1 September 1650, in Singlin A., Lettres d'Antoine Singlin, ed. A.-C. Josse (Paris: 2004) 322 (Letter 77).

43 See Singlin's letter to Chavigny of 1 September 1650, in ibid. 322 (Letter 77). On Bagnols, who was quite the model convert compared to Chavigny, see Neveu, "Un ami" 45-92.

44 Singlin's letter to Chavigny of 1 September 1650, in Singlin, Lettres 322 (Letter 77). While supportive, the timbre of Singlin's three extant letters to Chavigny is very different from, e.g., his instruction to Gué de Bagnols not to worry about his devotional sterility and susceptibility to distraction, but simply to avoid the world as much as he can; see Singlin's letter to Gué de Bagnols of 26 May 1651, in ibid. 339 (Letter 86). 
Grand-siècle observers queried devotional motives with keen suspicion. Chavigny was one of the figures whose possible conversion was scrutinized by the penetrating gaze of specialists. The Recueil d'Utrecht features an undated letter from Le Maistre to D'Andilly in which the count serves comparatively as a prototype of superficiality. The letter concerns the alleged conversion of an anonymous common friend, and Le Maistre is not convinced. He has heard such Christian words before in Chavigny, but they turned out to be nothing but sterile and fruitless phrases, and thus he fears, 'Peut-être que ce cher ami, comme M. de Chavigny, n'aura pas été huit jours à la Cour caressé \& favorisé des Majestés \& de l'Eminence, qu'il se trouvera tout tel qu'il étoit avant son affaire'45 ('Perhaps, like M. de Chavigny, our dear friend shall not have spent eight days at court, pampered and favoured by their Majesties and his Eminence, before he finds himself to be exactly what he was before this affair'). Mère Angélique seems to say the same, albeit in a more benevolent way, when she remarks that during the last four years of his life, Chavigny was often touched by God and incited to convert, and thus had begun to see Singlin 'avec de grands mouvemens de penitence' ('with great inner stirrings of penitence'), but that he was ever involved in worldly intrigues. The abbess recounts that when God finally let him fall into a fever, ${ }^{46}$ Chavigny called for Singlin and confessed his sins 'avec tous les sentimens de vraie pieté' ('all the sentiments pertaining to true piety'). An intense dialogue developed between Singlin and the medical doctors who did not deem the illness fatal and thus saw no need to give the count the Sacrament, and in this deplorable state, Chavigny lost consciousness and died soon after. ${ }^{47}$ Two months later Mère Angélique has more details to offer, and in a letter to the Polish queen conjures up a vivid portrait of the dying Chavigny scrambling to gather money for Singlin: 900,00o livres worth of bills of exchange from his cabinet and 300,000 livres in pistols from a casket in his chamber. ${ }^{48}$ Chavigny's ultimate donation aimed to signal

45 Undated letter from Le Maistre to D'Andilly, in Recueil de plusieurs pieces pour servir a l'histoire de Port-Royal (Utrecht, Aux Dépens de la Compagnie: 1740) 203-206, esp. 203204. See also the account of Singlin's suspicion vis-à-vis the advocate Nicolas Richer and his wife; Fontaine, Mémoires II 78-80.

46 Illness, be that of the convert in spe or the spouse, is a recurrent motif in conversion accounts; see, e.g., the description of Nicolas Richer's conversion in ibid. II 74-84, and that of Liancourt's in Boileau, "Avertissement" 8-27.

47 See Angélique Arnauld's letter to the Queen of Poland of 18 October 1652, in Lettres II 200-202 (Letter 489).

48 See Angélique Arnauld's letter to the Queen of Poland of 19 December 1652, in ibid. II 238 (Letter 507). Chavigny's wife did not know about these transactions, and since Chavigny had not signed the papers, his deathbed donation was followed by two months of deliberations, involving clergy, doctors from the Sorbonne, and friends of the widow. Eventually 
world-renunciation..$^{49}$ In Le cœur nouveau, Saint-Cyran had taught him that just like marriage and other worldly involvements, wealth ties human beings to the world. ${ }^{50}$ From Singlin's pulpit Chavigny might have heard the perils of wealth described in expositions of the general idea that the poor are an opportunity for the rich to demonstrate their love of God. ${ }^{51}$ If Chavigny was not entirely confident that he had managed to live as a spiritual pauper, he could at least divest himself of worldly riches as death drew near.

Summing up Chavigny's devotional profile, Lancelot informs us that the count wanted God

de le rendre également utile \& à l'Etat \& à l'Eglise: ce qu'il savoit bien ne se pouvoir faire qu'en le portant à travailler sérieusement à son salut; \&

the bulk of the money was returned to Mme de Chavigny. See Hermant, Mémoires I 670-697; Lesaulnier, "Chavigny" 258; and Josse, "Introduction" 102-107. Josse shows that Chavigny initiated this transaction in 1648; see ibid. 104; see also Sainte-Beuve, Port-Royal II $55^{2-569}$.

49 It is a hagiographic topos that world-renunciation is inspired by $M t$ 19:21: 'If you wish to be perfect, go, sell your possessions, and give the money to the poor, and you will have treasure in heaven; then come, follow me'. See, for example, Athanasius's Vita Antonii chapter 2. Anthony's example was available to Chavigny in Arnauld d'Andilly's translation, Les vies des saints pères des déserts (Paris, la veuve Jean Camusat and Pierre le Petit: 1647). On this influential work, see Bruun M. B., "A Solitude of Permeable Boundaries: The Abbey of La Trappe between Isolation and Engagement", in Göttler C. - Enenkel K. (eds.), Solitudo: Spaces, Places, and Times of Solitude in Late Medieval and Early Modern Europe, Intersections $5^{6}$ (Leiden: 2018) 451-479, esp. 453-455. As one step in his conversion, in 1642, the Duc de Liancourt made a promise to sell paintings from his collection, valued at 50,000 écus, and give the money to the poor if God would preserve his sick wife; Boileau comments that this was 'un vœu [...] de soumission' ('a vow of submission'); see Boileau, "Avertissement" 25-26, esp. 26. Liancourt and Chavigny's contrite appearance at PortRoyal in 1647 was likewise accompanied by pecuniary gifts; see Le Maistre, "Memoire" v. In his will of 1647 , Palus bequeathed to the brothers Séricourt and Le Maistre his furniture, silver, and books. Singlin pressed Palus had made his will, in order to ensure that his heirs would not bother Port-Royal and knowing that the legacy would be sold and given to the poor; see Le Maistre, "Memoire" IX-X. Chavigny was less sagacious. Bible quotations in English are given according to the New Revised Standard Version.

$50 \quad$ Saint-Cyran Jean Duvergier de Hauranne, abbé de, Le coeur nouveau, ov exercice pour une personne engagée dans le monde, \& dans le mariage, nouvellement convertie à Dieu, in Theologie familiere avec divers autres petits traitez de Devotion (Paris, la Veuve Jean Le Myre: 1643 ; reprint ed., 1669) 109-128, esp. 128.

51 Almsgiving is a response to $M t$ 19:21 (see above), but also to $M t$ 25:35-40, and specifically to Jesus's statement that he is present in the poor and the needy: 'for I was hungry and you gave me food, I was thirsty and you gave me something to drink, I was a stranger and you welcomed me [...]. Truly I tell you, just as you did it to one of the least of these who are members of my family, you did it to me'. On alms, see Singlin, "Instruction pour le Jour de Noel. Premiere instruction", in Instructions chrestiennes I 144-153, esp. 147-149. 
c'est ce qui lui faisoit continuellement demander à Dieu sa conversion. Cependant nous avons vu en lui combien il est dangereux d'être dans les grands engagements du siecle; car il ne put jamais executer les bons mouvements que Dieu lui donnoit de tems en tems, jusqu'à ce qu'enfin étant surpris de maladie il mourut en 1651 [sic]. ${ }^{52}$

to make him equally useful to the State and to the Church. This he knew well to be impossible without serious work on his salvation, which is why he continuously pleaded God for his conversion. However, we have seen in him how dangerous it is to be involved in grand worldly engagements, for he could never fully execute the good movements that God instilled in him from time to time, until he died surprised by illness in 1651 .

While Lancelot's memoir rehearses the topos that politics and religion are incompatible, in his funeral oration, the Oratorian Jean-Baptiste Noulleau (1604-1672) casts Chavigny as the pious statesman par excellence. ${ }^{53}$ The preacher presents the count as an embodiment of the qualities typical of the perfect statesman ${ }^{54}$ and as a victim of political misfortune, who heralds a new form of martyrdom, the 'Martyre de l'Estat'.55 Most important in our context is Noulleau's description of Chavigny's piety, exercised despite multiple traps, as he recalls how

Ce Comte parmy les plus grandes delices [...] de la Cour de France, est vn homme de Penitence, vn homme d'austerité! parmy l'abondãce de tant de bien, est vn homme de ieusne! \& pour les mieux pratiquer hors du monde; [...]; vn homme de retraitte! ${ }^{56}$

amidst the greatest pleasures [...] of the court of France, this count is a man of penitence, a man of austerity! Amidst this abundance of delights he is a man of fasting! And, in order that he might better practice these [inclinations] away from the world [...], a man of retreat!

$5^{2} \quad$ Lancelot, Mémoires I 183.

53 Noulleau Jean-Baptiste, Le grand Homme d'Estat selon toutes les maximes de la politique chrétienne, la seule vraie politique du monde (Rennes, J. Durand: 1653) $5^{-6}$. The funeral oration was delivered in the cathedral of Saint-Brieuc; Chavigny's cousin, Denis de La Barde, bishop of Saint-Brieuc (1600-1675) was the celebrant.

54 Ibid. 14-15. Chavigny is thus described as the opposite of irreligious politicians, 'tous les vrays Machiauellistes' ('all the veritable Machiavellists').

55 Ibid. 30.

56 Ibid. 16 . 
With such a character, Chavigny from time to time needed to breathe the air of a purer devotion, and therefore sought the cloister. Noulleau's mention of the count's retreat with Carthusians and Capuchins introduces an account of Chavigny's self-annihilating piety during his occasional retreats, and he describes the monastic cell as a sacred furnace where the count was gradually consumed by saintly love; it is compared to a pyre where this divine Phoenix each day died to himself and to the world and all its vanities in order daily to be recreated for the glory of God and Jesus Christ. ${ }^{57}$ From his retreat, Chavigny emerged like another Moses, offering to the world his example as a law to be followed. ${ }^{58}$ In order that he might teach by example, Providence impelled the disgraced Chavigny to engage in a new series of retreats at his houses in Champagne and the Tourraine. These retreats were were imposed on him by the spirit of God according to 'nostre saincte Escole; l'Escole du Crucifié59 ('our saintly School, the School of the Crucified'). Noulleau thus deftly turns Chavigny's fall from grace into a God-given estrangement from the world and into a persecution endured with Christ-like humility, and he identifies his exiles to the Château de Pont and the Château de Chavigny as eminent solitudes in the count's devotional universe.$^{60}$ While there is no doubt that the Oratorian deploys the hyperbole inherent to the genre, it is unlikely that he diverges radically from the truth. ${ }^{61}$ The funeral oration thus confirms the impression of Chavigny as a figure who engaged in some degree of religious practice, had some penchant for retreat, and from time to time embraced the discipline of penance, but whose devotional commitment was less staunch than that of the more fervent supporters of Port-Royal.

As Noulleau indicates, like many of his peers, Chavigny navigated a composite religious topography. The count was attached to his Parisian parish church,

57 On the idea that complete devotional absorption is a holocaust, an annihilation, see Belin C., La conversation intérieure: la méditation en France au xviie siècle (Paris: 2002) 99-111.

$58 \quad$ Noulleau, Le grand homme d'estat 16.

59 Ibid. 22.

6o For the topos of solitude in grand-siècle devotion, see Bruun, "A Solitude" 451-455.

61 I owe this insight to Anne Régent-Susini's expertise on seventeenth-century funeral orations; see her forthcoming monograph Le Marbre et la Cendre. L'oraison funèbre (1643-1715). 
Saint Paul, ${ }^{62}$ and to the parish priest, Nicolas Mazure. ${ }^{63}$ He was affiliated with religious institutions such as Port-Royal, the Capuchins of Pont-sur-Seine, and the Carthusians of Paris. ${ }^{64}$ To this topography, the spaces reserved for prayer and worship at the family castles also belong, and with his new chapel in Hôtel de Chavigny, the count added an important locus to this topography. Chavigny bought the Hôtel de Saint Paul in $1635 .{ }^{65}$ After some alterations in 1639, he began a more extensive renovation in 1642-1643, supervised by François Mansart (1598-1666), ${ }^{66}$ which was still incomplete when he died in $1652 .{ }^{67}$ People of the count's rank had chapels in their homes, ${ }^{68}$ and the masonry contract refers to a chapel that is to be built in 'ung residue de bastiment joignant la gallerye' ('an appendage to the building, adjoining the gallery'), adding that a special design will be supplied for this work. We lack this drawing, and the size and situation of the chapel are unclear, but the contract seems to indicate that

62 At least two of his daughters were baptised there; see "Gazette de Paris 5 April 1536", in Renaudot Théophraste, Recveil de tovtes les novvelles Ordinaires, Extraordinaires, Gazettes $\&$ autres Relations (Paris, Au Bureau d'Adresse: 1637) 220. Chavigny donated money to the chapel of St Jacques at Saint Paul, in March 1640; see AN L/697, fol. 11.

63 Hermant underscores the fact that at his deathbed Chavigny asked for Mazure's consent to confess to Singlin; see Hermant, Mémoires I 670-671. This remark speaks to Mazure's conviction that confessions should be made to the parish priest; see his L'obligation des fidelles de se confesser à leur curé suiuant le chap. 21 du concil general de Latran IV. (1653), which includes an attack against Jesuit confessors. Mazure was a supporter of Port-Royal; see Rapin, Mémoires I 130 and 112-113.

64 Noulleau says that Chavigny built a house adjacent to the convent of Pont-sur-Seine and had a cell in the Carthusian house of Paris; see Noulleau, Le grand homme d'estat 16. Rapin informs us that Chavigny attended conferences held by the Carthusian Dom Carrouge that were also frequented by friends of Port-Royal and were sites of political intrigue; see Rapin, Mémoires I 439. It is unclear whether the Carthusian cell mentioned by Rapin and Noulleau respectively is one and the same, and if so, which account is more accurate.

65 In 1641, he bought a neighbouring plot of land, which enabled an extension of the palace; see Le Guillou, Les Bouthillier 242.

66 Braham A. - Smith P., "François Mansart's work at the Hôtel de Chavigny", Gazette des Beaux Arts 66.2 (1965) 317-330, esp. 317, 320; and Braham A. - Smith P., François Mansart, 2 vols. (London: 1973) I 215-219, II 306-315. For the contracts, see Louis P.-Y. (ed.), François Mansart: les bâtiments: Marchés de travaux (1623-1665) (Paris: 1998) 215-235. On the history of the site, see Sellier C., "La caserne Sévigné", Procès-verbaux / Commission municipale du Vieux Paris, 30 May (1901) 80-86.

67 Braham - Smith, "François Mansart's work" 318.

68 Mérot A., Retraites mondaines: Aspects de la décoration intérieure à Paris, au xviie siècle (Paris: 1990); Gady A., Les hôtels particuliers de Paris: du Moyen âge à la Belle époque (Paris: 2008) 82-83. For antecedents, see Webb D., "Domestic Space and Devotion in the Middle Ages", in Hamilton S. - Spicer A. (eds.), Defining the Holy: Sacred Space in Medieval and Early Modern Europe (Farnham: 2006) 27-47. 
it was to be positioned on the second floor. ${ }^{69}$ As part of the general expansion, Chavigny commissioned Philippe de Champaigne to paint an Annunciation for the chapel. ${ }^{70}$ The religious space added to Hôtel de Chavigny had equivocal connotations. In Chavigny's world, private chapels were deemed privileged sites of devotional prolificacy and ambiguous spaces that required careful regulation. The terminology applied to such sites was pliable. The formal term chapelle domestique is used interchangeably with chapelle particulière $e^{71}$ and chapelle privée, ${ }^{72}$ while oratoire covers a broader range of locations, from chapel to chamber, and thus also a wider array of devotional practices, from Mass to prayer. ${ }^{73}$

Devotional texts esteem private chapels. They teach believers to seek God in solitude, and describe private oratories and chapels as key loci of a form of devotion which is different from, yet on a continuum with, the liturgy of the Church. ${ }^{74}$ Jean Suffren (1571-1641), the Jesuit confessor of Marie de Medici, is confident that the private oratory is a site of prolific meditation. He even uses the space itself as a meditative vehicle for the compositio loci, advising that during Advent the devout reader consecrate 'vostre Oratoire, ou vostre chambre' to a meditation on the Incarnate Word in the Virgin's womb; 'comme si c'estoit la chambre ou l'Oratoire de la Vierge enceinte, \& pleine de Dieu en Nazareth' ('as if it had been the chamber or the oratory of the Virgin, pregnant

69 Braham - Smith, "François Mansart's work" 328, states that the position of the chapel is unknown; Louis, François Mansart 220 refers to renovations done 'au second estage', and to the chapel 'qui sera attenant audict estage' ('which will be connected to this floor'). While common, a second-floor position is by no means standard; for example, the chapel at the Château de Pont was situated on the first floor, while the chapel that Mansart designed for the Hôtel de Nevers (1648-1652) was on the ground floor; see Mignot C., "Le château de Pont en Champagne, la 'maison aux champs' de Claude Bouthillier, surintendant des finances de Louis XIII", Monuments et mémoires de la Fondation Eugène Piot 84 (2005) 173-212, esp. 185; and Braham - Smith, François Mansart I 240.

70 Saint Georges Guillet de, Mémoires inédits sur la vie et les ouvrages des membres de l'Académie royale de peinture et de sculpture, eds. L. Dussieux - E. Soulié - Ph. De Chennevières - P. Mantz - A. de Montaiglon, 2 vols. (Paris: 1854) I 241-242.

71 See, for example, Arnauld Henri, Statuts du diocese d'Angers (Angers, Olivier Avril: 1680) 674 .

72 See, for example, Antoine Godeau, Ordonnances et instructions synodales (Paris, Jean Camusat - Pierre le Petit: 1644) 174.

73 Le Camus uses the two terms in tandem, 'Oratoires ou Chapelles privées'; see Le Camus Étienne, Ordonnances synodales $d v$ diocese de Grenoble (Grenoble - Lyon, Alexandre Giroud - Claude Rey: 1690) 243.

74 Bruun M. B., "Time Well Spent: Scheduling Private Devotion in Early Modern France", in Maber R. - Barker J. (eds.), Managing Time: Literature and Devotion in Early Modern France (Oxford: 2017) 35-68; Bruun M. B., "Prayer, Meditation, and Retreat" in Lyons J. D. (ed.), The Oxford Handbook of the Baroque (Oxford: 2018) 
and replete with God in Nazareth'). ${ }^{75}$ The thirty years during which Christ led a hidden life resonates with this space of secluded devotion, and Suffren suggests that his readers meditate on this unknown part of Christ's life when they cross the threshold to their private oratory. ${ }^{76}$

Funeral orations show les grands retreating to their oratoires to be alone with God. According to one such oration, Louis XIII would rather humble himself before God in his oratory than reign over people from his throne, and in order to relax from the strains of ruling, he would withdraw there, immersing himself in tearful prayer, kissing relics, and composing hymns. ${ }^{77}$ Readers were encouraged to follow Anne d'Autriche into her chapel and to observe her selfdebasement before God, ${ }^{78}$ and to envision Louis XIV's Queen, Maria Theresia (1638-1683), prostrate on the floor of her chapel, her arms spread out as if on a cross, or prompted to imagine that, when going on a journey, she would betake herself to the chapel at five in the morning and remain there until departure. ${ }^{79}$ Hagiographic texts showed reverence for private chapels. In his Meditations, the Jesuit Paul de Barry (1587-1661) explains how Saint Praxedes lodged people of virtue, offering them the best possible conditions, including the opportunity to 'se Communier dans vne chapelle domestique qu'elle auoit fait dresser \& embellir toute propre à cela' ('to take Communion in a domestic chapel that she had furnished and adorned to this end'), ${ }^{80}$ and in L'Annee Chrestienne Suffren invites his readers to envisage Philippo Neri (1515-1595) hearing Mass in a small chappelle domestique close to his chamber. ${ }^{81}$ Along with such Jesuit examples, it is important to underline that, as Hillman has shown, rigorist circles also cherished their private chapels. ${ }^{82}$

75 Suffren Jean, L'Annee Chrestienne, ov Le sainct et profitable employ du temps pour gaigner l'Éternité (Paris, Claude Sonnius and Denis Bechet: 1640-1641; reprint ed., 1642) II.1 95.

76 Ibid. II.1 634 .

77 Grillié Nicolas, Oraison funebre prononcee dans l'Eglise des Avgvstins de Paris [...] pour les Tres-Chrestien Roy de France \& de Nauarre, LOVYS LE IVSTE (Paris, Vuefue Martin Durand: 1643) 15, 17 .

78 Fromentières Jean-Louis de, Oraison funebre d'Anne d'Autriche infante d'Espagne, Reine de France, et mere du Roi (Paris, Sébastien Mabre-Cramoisy: 1666) 10.

79 David Claude, Oraison funebre de tres-haute et tres-puissante Princesse Marie-Therese d'Autriche, Reyne de France et de Navarre (Paris, Edme Couterot: 1684) 18-19. Another sermon tells how in her oratoire the queen opened her heart to Christ, rejoicing in the king's victories and mourning her dead children; see Fléchier Esprit, Oraison funebre de Marie Terese d'Autriche, Infante d'Espagne, Reine de France et de Navarre (Paris, Sébastien MabreCramoisy: 1684) 29.

$80 \quad$ Barry Paul de, Les Meditations de Philagie, povr tovs les iovrs de l'année, 2 vols. (Lyon, Philip. Bordes - Laurent Arnaud - Cl. Rigaud: 1649) II 318-319.

$81 \quad$ Suffren, L'Annee Chrestienne II.2 208.

82 Hillman, Female Piety 87-91. 
Authors of Church regulations were less enthusiastic. The Council of Trent had sought to curb masses said in private homes, ${ }^{83}$ and in the decades before and, especially, after Chavigny's renovation, private chapels feature regularly in ecclesiastical literature as an unavoidable, but suspicious phenomenon. It is unsurprising that episcopal permission is required both for dedicating such chapels and for celebrating Mass there, ${ }^{84}$ but even with episcopal blessing, private chapels are seen as fraught with risks of abuse. Their position is an issue: they are to be built far away from workshops and other rooms associated with ordinary life; no one is allowed to sleep above or below them; and their ideally remote position requires that the doors be locked in order to prevent anyone from sneaking in to sleep or conduct unseemly business. ${ }^{85}$ For rural areas, authorities stress that private chapels must be situated away from stables and dovecotes. ${ }^{86}$ The access must be tidy; no dumping of dung and garbage is permitted; the roof must not protrude so as to serve as shelter for animals; no dogs are allowed inside, just as doves and other birds must be prevented from nesting. ${ }^{87}$ Nor may chapels be close to the dairy, the wine cellar, the kitchen, or halls where people dine or dance. ${ }^{88}$ With his campaign against the aristocracy, Jean Richard (1615-1686) is above all bothered by people who position their chapel in an attic or in a cabinet next to a chamber. He writes that if the king comes to spend the night, he is never put up in the chapel because it is too modest for the king, and he complains that whereas Monsieur and Madame lodge in the most magnificent apartment of the house, Christ is crammed into a corner. ${ }^{89}$

Private chapels tend to compete with the parish church. Authorities enjoin their readers to attend their parish service at major liturgical feasts, and to be

83 Session 22 (17 Sept. 1562) decreed that Mass must not be celebrated in private houses ('privatis in domibus'); Canones et decreta sacrosancti oecuminici Concilii Tridentini (Rome: 1834; reprint ed., Leipzig: 1866) 122.

84 Godeau, Ordonnances 174-175.

85 Ibid. 174; similar prohibitions are outlined in Le Camus, Ordonnances 242.

86 The position adjacent to the dovecote is particularly troublesome; see also Arnauld, Statuts 353 .

$87 \quad$ La Croix Claude de, Le parfaict ecclesiastiqve ov Diverses instrvctions sur toutes les fonctions Clericales (Paris, Pierre de Bresche: 1666) 568.

88 Le Camus, Ordonnances 243.

89 Richard Jean, Pratiques de pieté pour honorer le S. Sacrement, tirées de la Doctrine des Conciles \& des Saints Peres (Cologne, Balthasar d'Egmond: 1683) 155. This seems to hold true for Louis Le Vau's Hôtel Lambert (built 1640-1644). Ayers comments that '[n]o space was wasted at the Hôtel Lambert, the chapel, for example, being squeezed into the gap between the library and the party wall of the neighbouring building, on top of the stables'. See Ayers A., The Architecture of Paris: An Architectural Guide (Stuttgart - London: 2004) 86. 
good examples to their fellow Christians. ${ }^{90}$ Rites must be celebrated there, and thus no Mass is to be held in a private chapel in connection with the distribution of the viaticum; ${ }^{91}$ penitence can be administered there only with written episcopal permission; ${ }^{92}$ and there can be no baptism or churching of women. ${ }^{93}$ It is particularly important that les grands show up in their parish church and submit to the discipline of hearing Mass:

[...] à l'heure reglée pour tous les Paroissiens, \& de l'entendre avec tous les autres qui leur sont inferieurs, comme s'ils leur étoient égaux. L'Eglise dans ses prieres, \& dans l'administration des Sacramens, agissant toûjours avec égalité. ${ }^{4}$

$[\ldots]$ at the hours decreed for all parishioners and to hear it with all the others who are their inferiors, as if they were equal. In its prayers, in its administration of the Sacraments, the Church always conducts itself with equality.

If parishioners neglect their parish church, they miss Masses, processions, benedictions, sermons, and important announcements - often at the risk of deadly $\sin ^{95}$ The private chapel resembles a church, but is not a church. Liturgical furnishings, vestments, and vessels are a sine qua non; but while La Croix allows that a small bell be used to gather the household for communal prayer evenings and, if possible, mornings, ${ }^{96}$ Le Camus is adamant that private chapels must forgo bells in order not to draw people away from the parish church. ${ }^{97}$

$90 \quad$ Godeau, Ordonnances 175; see also Démia Charles, Tresor clerical ou Conduites pour acquerir et conserver la Sainteté Ecclesiastique, recueilli des Autheurs les plus considerables de ce temps, qui ont traité de ces matieres (Lyon, Jean Certe: 1682) 508.

91 See, for example, the catechism of Claude Joly, bishop of Agen, Les devoirs dv chrestien dresses en forme de catechisme [...] en favevr des cvrez \& des Fidelles de son Diocese (Paris, Pierre le Petit: 1677) 371.

92 Ibid. 205.

93 Le Camus, Ordonnances 244.

94 Richard, Pratiques de pieté 156. Other authors do not wish les grands to subject themselves to religious égalité, but to deploy their rank to be good models in the parish church; see Bruun M. B. - Nørgaard L. - Nagelsmit E. - Havsteen S. R. - Mejrup K., "Withdrawn amidst the World: Rancé's Conduite chrétienne for Mme de Guise (1697)", Early Modern French Studies 39.1 (2017) 57-74.

95 La Croix, Le parfaict ecclesiastiqve 566.

96 Ibid. 568 .

97 Le Camus, Ordonnances 244. La Croix prescribes that the chapel must have four chasubles in white, red, green, and violet, each with a stole and maniple, two albs, two belts, and three amices. For the altar three napkins, two candlesticks, a cross, a crucifix, and the 
Along somewhat similar lines, commentators fear that the staffing of private chapels is a way to circumvent the controls usually applied to churches. La Croix complains that private chapels are often used by women and peasants who cannot assess the quality of the preacher's Latin, and Le Camus fears that lay owners of private chapels call on the services of random vagrant preachers. ${ }^{98}$

A last recurrent issue is the inappropriate mixture of sacred and profane that bedevils the private chapel. Authorities repeat that rural chapels are not to be used for storage of sheaves and fruit. ${ }^{99}$ Observers of chapels in large households comment how difficult it is to preserve the proper sanctity when the chapel is managed by a common servant; when liturgical textiles are washed and bleached together with the common linen; and when people attend Mass in an undignified attire, unkempt and half-dressed. ${ }^{100}$ Richard regrets the modish air that surrounds this space and which he presents as heavily gendered. Recalling how Felix IV (d. 530) found that it is better not to say Mass than to say it in a non-consecrated space, he muses about what the saint would have said,

[...] voyant tant de Chapelles domestiques, dans lesquelles on offre presque tous les jours le Corps de Nôtre-Seigneur Jesus-Christ sans autre necessité, que de contenter la devotion douce \& aisée des femmes qui l'entendent souvent de leur lit, \& qui tiennent le Cercle où l'on a offert le plus saint, le plus auguste, \& le plus terrible de nos Mysteres? Cet abus est si public par la coûtume, que peu de personnes ouvrent les yeux pour le connoître. ${ }^{101}$

Canon. The front of the altar must be in the liturgical colours, and above the altar there must be either a painting or a piece of textile. The chapel must have a cover for the altar, as well as a chalice and a paten of gilded silver, two palls covered in white linen, as many veils as there are chasubles, burses, and purificators, a Roman Missal, a cushion, and an altar bell, a candlestick for the Gospel side, crewets, an oval basin, and four hand towels; see Le parfaict ecclesiastiqve $568-570$. Most of these recommendations reappear in Démia, Tresor clerical 506-508.

98 Le Camus, Ordonnances 239.

99 Arnauld, Statuts 674.

100 La Croix, Le parfaict ecclesiastiqve 566. But see Suffren's counsel that readers begin their morning prayers as soon as they have dressed according to health and propriety; Suffren Jean, Advis et exercises spiritvels pour bien employer les iours, les semaines, les mois \& les années de la vie (Paris, Claude Sonnius - Denis Bechet: 1642; reprint ed., 1646) $5{ }^{2-55}$.

101 Richard, Pratiques de pieté 154-155; possibly, 'la devotion aisée' opposes the 'easy devotion' propagated in works such as Pierre Le Moyne's Dévotion aisée (Paris, Antoine de Sommaville: $\left.165^{2}\right)$. 
[...] seeing so many domestic chapels where one offers almost daily the Body of our Lord, Jesus Christ, without any other motive than to satisfy the soft and easy devotion of women who often hear [Mass] from their beds, and [ladies gather] ${ }^{102}$ where one has offered the most holy, the most august, and the most terrifying of our mysteries? This abuse has now become so general and so common that few people open their eyes to it.

Richard finds that private chapels nourish the lack of devotion in the rich and mighty who have become so accustomed to hearing Mass in confraternities, congregations, and domestic chapels that mingling with the common people at the parish Mass has become unbearable to them. ${ }^{103}$ Priests who, when by the altar, are viewed as messengers of God, are treated like paid domestics who eat with the servants and are paid for only half an hour's service per day. Thus one priest, completely vested and ready to say Mass, was told by a lackey to wait, since Madame had not yet had her hair done. ${ }^{104}$ Worst of all, the owners of private chapels show disrespect for God's sovereign majesty, no longer seeking God, but simply making him come to their home. ${ }^{105}$ Richard concludes that owing to private chapels, priests have lapsed and most parishes have fallen into ruin and desolation. ${ }^{106}$

This quick sketch of the grand-siècle view of private chapels warns us not to jump to conclusions about the devotional significance of the chapel at the Hôtel de Chavigny. Chavigny's new chapel accorded with the conventions of his class and age, and albeit later, Richard's jibes at the chic levity that surrounded private chapels may easily have applied to his chapel too. In fact, Rapin discretely hints at various abuses in his account of Chavigny's death, telling how Anne Phélypeaux, when she learnt upon rising that her husband had shut himself up with Singlin, 'Elle se lève, se fait habiller à demy par ses femmes pour aller entendre la messe en sa chapelle domestique, parce qu'il étoit fête' ('She got up, had her ladies dress her halfway and went to hear Mass in her domestic chapel, since it was a holiday'). After Mass, she went down to her husband's

102 'Tiennent le cercle' [literally, 'hold the circle'] signifies in this context the princesses and duchesses surrounding the queen.

103 Richard, Pratiques de pieté 155. Mme de Liancourt's assurance to her granddaughter that even though she has permission to hear Mass in her domestic chapel, she preferred to go to her parish church, should be read in the light of such decrees; see Liancourt Jeanne de Schomberg Duchesse de, Reglement donné par une dame de haute qualité a $M^{* * * *}$ sa petitefille Pour sa Conduite, \& pour celle de sa Maison, avec un sutre Reglement que cette Dame avoit dressé pour elle-mesme (Paris, Augustin Leguerrier, 1698) 207.

104 Richard, Pratiques de pieté, pratique $155^{-156 .}$

105 Ibid. 156.

106 Ibid. 159 . 
apartment and finding him drowsy, returned to her room to dress. ${ }^{107}$ Rapin's remark that Anne Phélypeaux wanted to hear Mass in the private chapel on a liturgical feast day already has a disturbing ring, but even more striking is his aside that she went to the chapel half-dressed and only dressed properly later.

However, we should not reject out of hand the devotional significance of the chapel. In Le cour nouveau, Saint-Cyran taught Chavigny to retreat on a daily basis and to resort to silent prayer whenever the world encroached on his love of God. Such retreats did not depend on physical isolation, but the chapel would have afforded one place fitted to these prayers. ${ }^{108}$ Noulleau, for one, was adamant that Chavigny experienced moments of genuine religious transformation in his palaces. His audience would have been familiar with the topos of the home as a locus of devotion with the private oratory at its heart, and they would likely have accepted the preacher's presentation of Chavigny's houses as religious retreats. In order to get a better sense of the dynamics ideally at play in such a retreat, we shall consider the painting that adorned the chapel at the Hôtel de Chavigny.

The Painting

Chavigny's turn to Philippe de Champaigne was not a one-off. He also commissioned an Assumption for Saint Germain l'Auxerrois (ca. 1638) ${ }^{109}$ and probably a Presentation in the Temple (ca. 1630). ${ }^{110}$ His choice of painter accords with his parents' patronage of Champaigne, ${ }^{111}$ and given that Champaigne portrayed Chavigny's father, ${ }^{112}$ his mother, ${ }^{113}$ his uncle Victor, ${ }^{114}$ and possibly

\footnotetext{
107 Rapin, Mémoires I 467.

108 Saint-Cyran, Le coeur nouveau 118.

109 Gonçalves J., Philippe de Champaigne: le patriarche de la peinture (Paris: 1995) 47-48.

110 Tapié A. - Garnot N. S. F. et al., Philippe de Champaigne (1602-1674) entre politique et dévotion (Paris: 2007) 87-89; and Gonçalves J., Philippe de Champaigne: La vie, l'ouvre et le catalogue en cinq livres [...]. Catalogue des peintures, dessins et désattributions. Nouvelle édition revue et corrigée (April 2013 [2008]) http://www.josegoncalves.fr/tronc/PdCcatalogue-2013-fusionn\%C3\%A9.pdf (21.05.2018), cat. 1, 36 .

111 See for this patronage, Gonçalves, Philippe de Champaigne cat. 1, 25-27 and 41, as well as 6, 4-5; Kerspern S., "Un décor d'église inconnu de Philippe de Champaigne?", Revue de l'Art 118, 4 (1997) 78-80; and http://www.dhistoire-et-dart.com/Fortunecritique/ Champaignejeune2s4.html (19.06.2018).

112 See Gonçalves, Philippe de Champaigne cat. 1, 49.

113 Champaigne painted Marie Bragelogne in 1630-1635, ca. 1646-1648, and ca. 1652-1653; see Dorival, Philippe de Champaigne 1602-1674, 2 vols. (Paris: 1976) I 87, nos 151-153.

114 Dated to 1650; see Gonçalves, Philippe de Champaigne cat. 2, 47; and Tapié - Garnot, Philippe de Champaigne 174-175.
} 
Chavigny himself, ${ }^{115}$ it is likely that in choosing Champaigne, the count simply continued the familial predilection. His choice may also have been assertively careerist. By the first half of the 1640 , the Flemish painter was cherished in prominent circles, and the count was perhaps mimicking Richelieu for whom Champaigne painted no fewer than ten portraits. ${ }^{116}$ Félibien points to Champaigne's portraits of the king, the queen, and the dauphin in 1641 as evidence of his fame, ${ }^{117}$ and when Anne d'Autriche moved into the Palais-Royal in 1643, she commissioned an Annunciation for her chapel.118

Champaigne's painting for Chavigny has been seen in the light of Jansenism, ${ }^{119}$ but if Chavigny commissioned the painting in $1642-1643$, it precedes Champaigne's close connection with Port-Royal by a few years. ${ }^{120}$ While scholars debate whether Champaigne can be described as a 'Jansenist painter', ${ }^{\prime 21}$ his growing connection with Port-Royal is clear only from the mid${ }^{1640 s}{ }^{122}$ In the period $1646-1667$, Champaigne painted several portraits of Port-Royal figures, two paintings for the convent of Port-Royal (1648), and one for Port-Royal des Champs (ca. 1652). ${ }^{123}$ His daughters entered the school at

115 Gonçalves dates the Champaigne portrait, which probably underlies Nanteuil's engraving, ca. 1656, i.e., after the model's death; see Philippe de Champaigne cat. 6, 45. See also Dorival, Philippe de Champaigne I 133.

116 See ibid. II passim; see also Garnot N. S. F., "Philippe de Champaigne et ses commanditaires", in Boyer J.-C. - Gaehtgens B. - Gady B. (eds.), Richelieu patron des art (Paris: 2009) 395-406, esp. 395 and 405.

117 Félibien André, Entretiens sur les vies et sur les ouvrages des plus excellens peintres anciens et modernes, cinquième partie (Paris, Sébastien Mabre-Cramoisy: 1688) 173.

118 Bertrand A., Art and politics in Counter-Reformation Paris: The Case of Philippe de Champaigne and his Patrons (1621-1674), Ph.D. dissertation (University of Pittsburgh: 2001) 277-278. Garnot dates the Annunciation produced for Anne d'Autriche's chapel 1643; see Tapié - Garnot, Philippe de Champaigne 130.

119 Allden M. - Beresford R., "Two Altar-Pieces by Philippe de Champaigne: Their History and Technique", The Burlington Magazine 131.1035 (1989) 395-406, esp. 395-396.

120 According to Marin, this connection begins ca. 1644-1645; see Marin L., Philippe de Champaigne: Ou la présence cachée (Paris: 1995) 245. See also Marin, "Signe et représentation: Philippe de Champaigne et Port-Royal", Annales 25.1 (1970) 1-29, esp. 7, where he dates Champaigne's turn to Port-Royal between 1643 and 1648; and Tapié A. - Garnot N. S. F., "Dialogues avec Port-Royal: une pensée picturale (1646-1662)", in Tapié - Garnot et al., Philippe de Champaigne (1602-1674) entre politique et dévotion (Paris: 2007) 147-217, esp. 147.

121 Famously, Marin is convinced that he is; see Marin, "Signe et représentation" and Philippe de Champaigne. This notion is thoughtfully challenged in Cojannot-Le Blanc M., "La foi et les oeuvres: Postface sur l'oeuvre peint de Philippe de Champaigne et ses possibles liens avec la spritualite de Port-Royal", in Cojannot-Le Blanc M. (ed.), Philippe de Champaigne ou la figure du peintre janseniste (Paris: 2011) 171-216.

122 Cojannot-Le Blanc, "La foi et les œuvres" 200.

123 See Tapié - Garnot, Philippe de Champaigne 147-219; and Pericolo L., Philippe de Champaigne: "Philippe, homme sage et vertueux". Essai sur l'art et l'oeuvre de Philippe de Champaigne (1602-1674) (Tournai - Bruxelles: 2002) 228-262. 
Port-Royal in $1648,{ }^{124}$ and the same year he designed the frontispiece for the second edition of Traité de la fréquente communion. ${ }^{125}$ When Chavigny commissioned his new chapel, however, Champaigne was above all a favourite of the grands dévots, and the patronage of the count's family, his political aspirations, and the aristocratic penchant for the Flemish artist were likely his principal incentives.

The Annunciation was a popular motif for paintings in private chapels. To mention but a few examples, Champaigne painted an Annunciation for the chapel at the Château Tubeuf $(1644-1645)^{126}$ and one for Anne d'Autriche's oratory at the Palais-Royal (ca. 1643). ${ }^{127}$ The chapel of the Hôtel de Brienne had an Annunciation, ${ }^{128}$ and in 1650 Eustache Le Sueur (1616-1655) produced one for the chapel of the Hôtel de Brissonnet (later Turgot). ${ }^{129}$ Closely related to the Annunciation as a subject focussing on the mystery of the Incarnation, the Nativity was also favoured for private chapels. The chapel of the Hôtel de Liancourt was graced by a Nativity; ${ }^{130}$ Château de Pont had one, perhaps painted by Champaigne; ${ }^{131}$ and the oratory of Charlotte-Marguerite de Montmorency (1594-1650) at the Hôtel de Condé had a Nativity by Le Sueur. ${ }^{132}$

According to Dorival, sources predating the Revolution list seventeen Annunciations by Champaigne, ten of which still exist. ${ }^{133}$ Three of these paintings have been identified as the Annunciation produced for the Hôtel de Chavigny. Dorival claims that the Annunciation currently in the church of Clermont-Ferrand is 'without doubt' the one commissioned by Chavigny and dates it 1639 [Fig. 20.2]. ${ }^{134}$ In his catalogue of the Wallace Collection, John

124 Tapié - Garnot, "Dialogues avec Port-Royal" 147; and Lesaulnier J., "Philippe de Champaigne et Port-Royal: Les leçons d'une correspondance”, in Cojannot-Le Blanc M. (ed.), Philippe de Champaigne ou la figure du peintre janséniste (Paris: 2011) 13-29, esp. 13-14. See also Tapié - Garnot, Philippe de Champaigne 192-196.

125 Marin, "Signe et représentation" 7; and Cojannot-Le Blanc M., "La foi et les œuvres" 200.

126 D'Argenville Antoine Joseph Dezallier, Abrégé de la vie des plus fameux peintres, avec leurs portraits gravés en taille-douce, les indications de leurs principaux ouvrages, 3 vols. (Paris, de Bure l'Aîné: 1745) II 184.

127 Garnot N. S. F., "L'Annonciation, vers 1642", in Tapié - Garnot, Philippe de Champaigne 129-131, esp. 130.

128 Hillman, Female Piety 88, note 159.

129 Mérot A., Eustache Le Sueur (1616-1655) (Paris: 1987) 245-246; and D’Argenville, Abrégé II 297.

130 Hillman, Female Piety 88. It was probably painted by Francesco da Ponte Bassano the Elder (1475-1530).

131 Mignot, "Le château de Pont" 207.

132 Mérot, Eustache Le Sueur 346-347, with a suggested date of ca. $165^{\circ}$.

133 Dorival B., "Les oeuvres de Philippe de Champaigne sur le subjet de l'Annonciation", Bulletin de la société de l'histoire de l'Art Français (1970; publ. 1972) 45-71, esp. 50.

134 Dorival, Philippe de Champaigne II 19, no. 22. The painting measures $260 \times 210 \mathrm{~cm}$. 


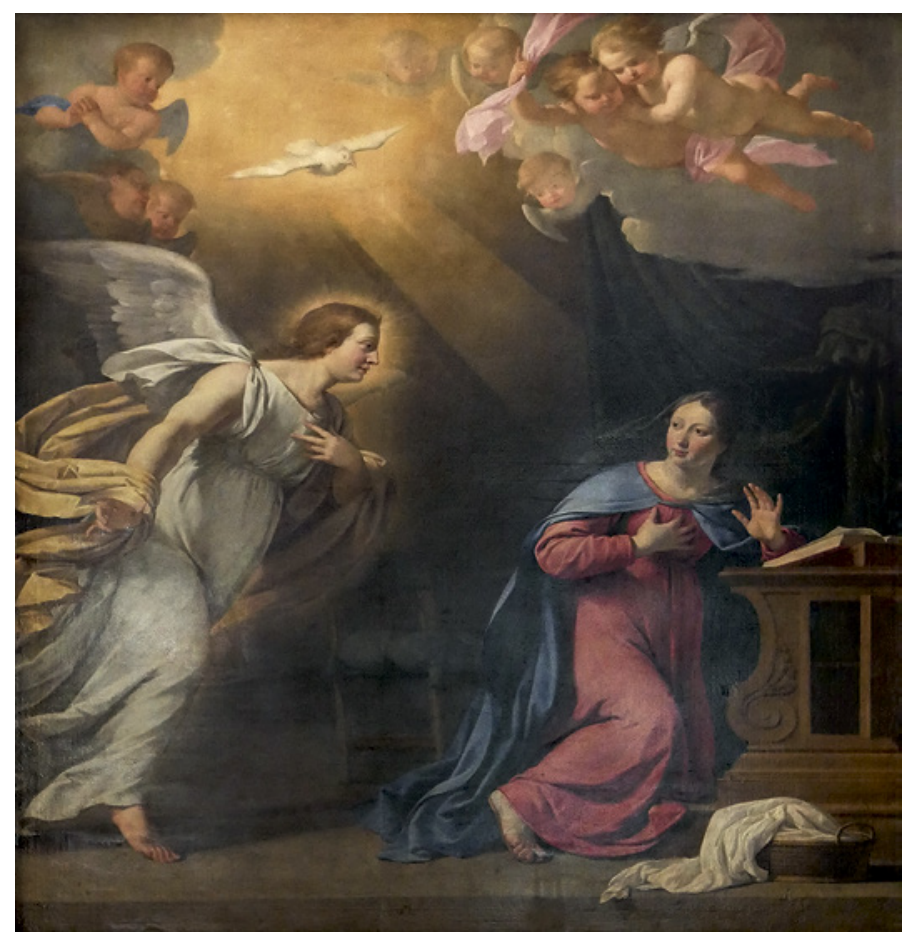

FIgURE 20.2 Philippe de Champaigne, Annunciation, ca. 1639.

Oil on wood, $260 \times 210 \mathrm{~cm}$. Notre-Dame-du-Port de

Clermont-Ferrand

PHOTOGRAPH BY QUENTINEO (2018)

Ingamells proposes, however, that that museum's Annunciation may have been produced for Hôtel de Chavigny between 1643 and $1648,{ }^{135}$ and suggests that the 'unusual austerity of the composition' might have been appealing to a 'patron with Jansenist sympathies' [Fig. 20.3]. ${ }^{136}$ Ingamells's hypothesis is corroborated by Allden and Beresford, who strengthen the Jansenist argument and find that the substantial size of the Wallace Annuncation is compatible with the fact that Chavigny built a chapel rather than a private oratory. ${ }^{137}$ Both

135 Ingamells J., The Wallace Collection: Catalogue of Pictures III: French before 1815 (London: 1989) 111. The painting measures $334 \times 214.5 \mathrm{~cm}$.

$136 \quad$ Ibid. 111.

137 Allden - Beresford, "Two Altar-Pieces" 395-396. Garnot associates the Wallace Annunciation with altarpiece made by Champaigne for Sainte Catherine de la Couture, which was situated opposite Hôtel de Chavigny; see Garnot, "Philippe de Champaigne" 403; and D'Argenville, Abrégé II 184. Gonçalves dates this painting 1654-1656 and associates it with the chapel of Saint Anne in Anne d'Autriche's Val-de-Grâce; see Philippe de Champaigne cat. 3,15 and 16 . 


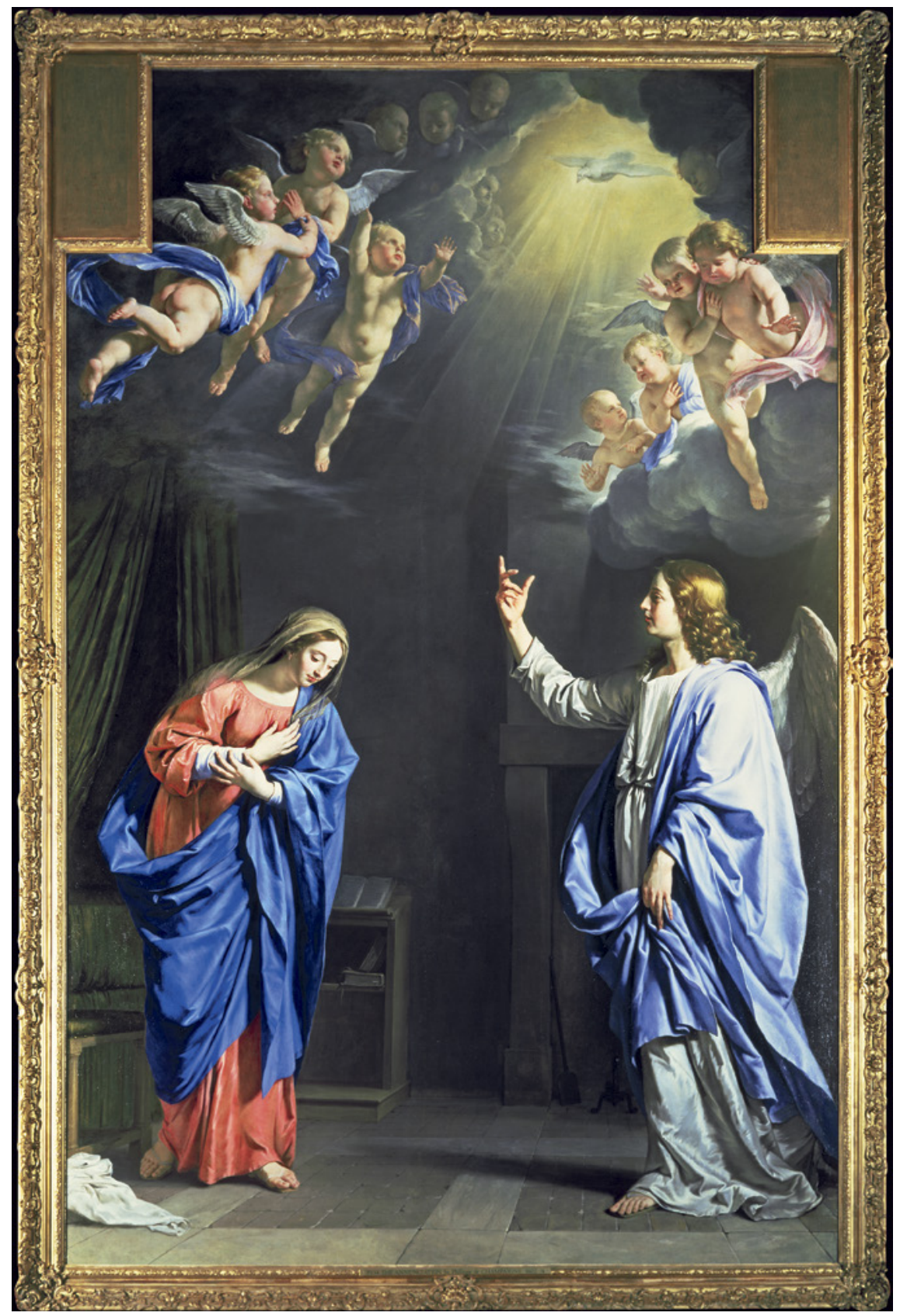

FIGURE 20.3 Philippe de Champaigne, Annunciation, ca. 1648 . Oil on canvas, $334 \times 214.5 \mathrm{~cm}$ (C) THE WALLACE COLLECTION, LONDON 


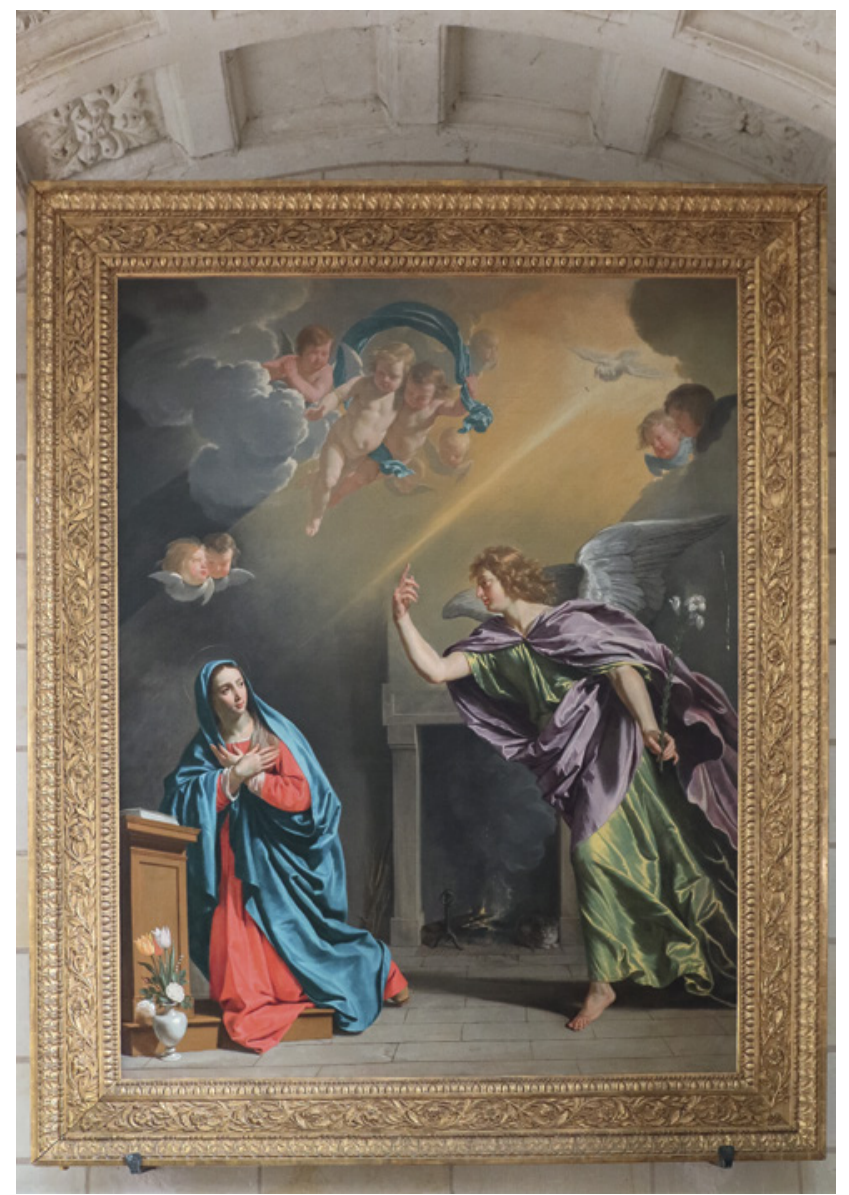

FIGURE 20.4 Philippe de Champaigne, Annunciation, ca. 1643. Oil on canvas, $215 \times 170 \mathrm{~cm}$. Saint-Jean-Baptiste de Montrésor PHOTOGRAPH BY ALAIN CROZEMARIE (2015)

Gonçalves and Garnot argue instead that the Champaigne Annunciation, which is currently in the church of Saint-Jean-Baptiste in Montrésor, originally graced the chapel of the Hôtel de Chavigny, ${ }^{138}$ and date it 1642-1643, contemporaneous with the campaign of renovation [Fig. 20.4].139

138 Garnot, "L'Annonciation" 129-131; and Garnot, "Philippe de Champaigne" 398-400. In the latter, Garnot confuses Claude and Léon Bouthillier and ascribes the association with Richelieu to the proximity of their estates in the Tourraine, rather than to their shared upbringing. The painting measures $215 \times 170 \mathrm{~cm}$.

139 Garnot dates the painting toward the end of 1642; see "Philippe de Champaigne" 400. Similar conclusions are drawn in Gonçalves, Philippe de Champaigne cat. 2, 12, but he 
Garnot and Gonçalves argue persuasively for their association of the Annunciation in Montrésor with the Hôtel de Chavigny, but the identification of Chavigny's painting still seems too uncertain to warrant any in-depth correlation of the count's devotional preferences and Champaigne's execution of the motif of the Annunciation. Nonetheless, it is worthwhile lingering over the three Annunciations that have been linked to the Hôtel de Chavigny (here identified by their current location) as a prelude to our study of the way in which Chavigny would have beheld the one he owned. The three paintings share a set of basic features. They all represent Mary and Gabriel in an indoor space with a few pieces of furniture; all hint at communication between the two figures; all show a ray of light emanating from the dove of the Holy Spirit accompanied by clouds and angels; and in all of them Mary bears the traces of a smile and gestures toward her heart. Some features occur only in two paintings. Thus, while the Montrésor and the Clermont-Ferrand Annunciations show Mary kneeling at her prie-dieu and looking at the angel Gabriel who has just alighted (cf. Lk 1:28-29), the Wallace Annunciation portrays Mary with lowered eyes, responding 'Ecce ancilla Domini' - 'Here am I, the servant of the Lord' ( $L k$ 1:38). The light of divine grace flows towards Mary, but in different ways. In the Montrésor Annunciation, the ray is a straight line, extending in the direction of her eyes; in the Clermont-Ferrand Annunciation, the light envelopes her upper body; and in the Wallace Annunciation, the light proliferates into several rays, showering the entire scenery, but always in Mary's direction. The interaction between Mary and Gabriel is shown in different ways too; in the Wallace and the Montrésor Annunciations, Gabriel points upwards, while in the Clermont-Ferrand Annunciation, both the Virgin and the angel place hand to heart in a reciprocal gesture. In the Clermont-Ferrand Annunciation, Mary's lifted hand signals her surprise; the Wallace and the Montrésor Annunciations show her with arms crossed in a gesture of submission and humility. ${ }^{140}$ The paintings feature different topoi, and while the Clermont-Ferrand and the Wallace Annunciations both include swaddling bands spread out on the floora possible double allusion to the infant Moses as a prefiguration of Christ and to the shroud of the Passion - the Montrésor Annunciation features the more

dates the Montrésor Annunciation ca. 1636, in Philippe de Champaigne 148. Pericolo dates the Montrésor Annunciation 1638-1640 and associates it with the Jesuit noviciate in the faubourg Saint-Germain, but does not comment on the Hôtel de Chavigny; see Pericolo, Philippe de Champaigne 105.

140 Krüger K., "Mute Mysteries of the Divine Logos: On the Pictorial Poetics of Incarnation", in Melion W. - Wandel L. P. (eds.), Image and Incarnation in Early Modern Doctrine of the Pictorial Image, Intersections 39 (Leiden - Boston: 2015) 76-108, esp. 86; see also Rubin M., Mother of God (New Haven - London: 2007) 343. 
standard vase of flowers. In the Montrésor Annunciation, Gabriel holds a lily; in the others, he is empty-handed. In the Wallace Annunciation, both figures stand, and Gabriel seems virtually motionless, whereas he moves dynamically in the other two. Finally, in the Montrésor Annunciation, the background is arranged perspectivally. Garnot suggests that the fireplace in the background conveys a sense of domestic familiarity, but possibly the fireplace with its smoking embers and the cat, an icon of lust, ${ }^{141}$ serves above all as the symbolic earthly foil for the radiant light of grace signifying Mary's chastity.

No matter which of the three paintings hung in Chavigny's chapel, the count would thus have had before him a representation of the indoor meeting between Gabriel and Mary, accompanied by a host of angels, lit by the radiant light of divine grace, and engaged in an encounter comprised by gaze and gesture, ${ }^{142}$ all converging in the representation of the origin of the mystery of the Incarnation.

We do not know how Chavigny gazed at his painting, but we do have an idea of the kind of viewing experience that Saint-Cyran and Singlin tried to instil in him. This is a gaze shaped by the intersection of the discourses of conversion, prayer, and of contemplation of the mystery of the Incarnation. While the two key Port-Royalist figures strive to activate the eyes of the heart, their ideal gaze is very different from the spiritual gaze rehearsed in Jesuit, Salesian, and mystical prayer manuals and from the interaction between the carnal eyes and the eyes of the soul evoked in those contexts. ${ }^{143}$ The gaze that SaintCyran and Singlin sought to teach does not aim to shape or explore mental

141 Ross L., Medieval Art: A Topical Dictionary (Westport - London: 1996) 14.

142 See, on their interaction, Krüger K., "Mute Mysteries" 76-108.

143 On early modern instruction in the formation of mental images, see Boer W. de - Enenkel K. - Melion W. S. (eds.), Jesuit Image Theory, Intersections 45 (Leiden - Boston: 2016); Melion W. S. - Dekoninck R. - Guiderdoni-Bruslé A. (eds.), Ut pictura meditatio: The Meditative Image in Northern Art, 1500-1700 (Turnhout: 2012), esp. Melion, "Meditative Images and the Portrayal of Image-Based Meditation" 1-6o and Cousinié F., "The Mental Image in Representation: Jean Aumont, L'Ouverture intérieure du royaume de l'Agneau occis dans nos cœurs (1660)" 203-246; Boer W. de, "Invisible Contemplation: A Paradox in the Spiritual Exercises", in Enenkel K. - Melion W. S. (eds.), Meditatio - Refashioning the Self: Theory and Practice in Late Medieval and Early Modern Intellectual Culture, Intersections 17 (Leiden - Boston: 2010) 235-256; and Fabre P.-A., Ignace de Loyola: Le lieu de l'image. Le problème de la composition de lieu dans les pratiques spirituelles et artistiques jésuites de la seconde moitié du XVI ${ }^{e}$ siècle (Paris: 1992). On meditative imagination in De 
images; instead the Port-Royalist conception of the gaze of the heart aims to divest the soul of most images, leaving only the imprint of its own humility and the grace of God. Important is the fact that contrary to Jesuit image theory, the gaze imparted to Chavigny is not defined in relation to material images. It is true that the alleged Port-Royalist opposition to images does not apply to SaintCyran's Le cour nouveau, written before he became the director of the convent, in which he instructs Chavigny to make use of images as a means of devotional nourishment. ${ }^{144}$ To my knowledge, Singlin does not voice any strong opposition toward material images either - he simply does not mention them; ${ }^{145}$ the images of interest to him are above all the biblical figures who serve as portrayals of qualities or virtues. Thus, according to Singlin, Jesus puts forward the tax collector in Lk 18:9-14 as an image excellente of penitence; ${ }^{146}$ the Canaanite woman (Mt 15:21-28) as an image of trust; the hemorrhagic woman (Mt 9:2022) as an image of faith; Mary Magdalene as an image of charity, penitence, and conversion; ${ }^{147}$ and Paul as an image of conversion. ${ }^{148}$ Learning to see the deep implication of such written images and to adopt the virtues they exhibit is the first step taught in Singlin's instructions; applying the eyes of the heart is the second.

Conversion is the condition, the impetus, and the aim of this gaze, and with this in mind, we shall begin with an examination of Le cour nouveau, the treatise on conversion that Saint-Cyran wrote for Chavigny. The new heart of the title refers to Ezek 36:26, quoted at the opening: 'Ie vous donneray un Cour nouveau, \& je mettray un esprit nouveau au milieu de vous; Ie vous osteray vostre cœur de pierre, \& vous en donneray un de chair.' ('A new heart I will give you, and a new spirit I will put within you; and I will remove from your body the heart of stone and give you a heart of flesh.'). ${ }^{149}$ The biblical and, in particular, Pauline concern with cordial renewal is key to grand-siècle conversions.

Sales, see Lyons J. D., Before Imagination: Embodied Thought from Montaigne to Rousseau (Palo Alto: 2005) 61-89.

144 See Saint-Cyran, Le coeur nouveau 118, discussed below.

145 For a succinct paraphrase of the discussion regarding the Port-Royalist opposition against the visual arts, see Martin É. M., Port-Royal Aesthetics, Ph.D. dissertation (Princeton University: 2006) 6-10.

146 Singlin, "Instruction pour le X'. Dimanche après la Pentecoste", in Instructions chrestiennes IV 202-212, esp. 203.

147 These three images all appear in Singlin, "Instruction pour le Jour de Sainte Magdelaine: Cinquième instruction", in Instructions chrestiennes IV 405-415, esp. 412-414.

148 Singlin, "Instruction Pour le Jour de la Conversion de Saint Paul", in Instructions chrestiennes I 700-709 (701).

149 Saint-Cyran, Le coeur nouveau 109. The Ezekiel reference is erroneously given as chapter 16 instead of chapter 36 . 
This notion of cordial renewal gained ground with François de Sales's seminal Introduction à la vie dévote (1609/1619), ${ }^{150}$ and it continued to develop throughout the century, as the Salesian ideals filtered down into manuals and devotional practices; as the heart as a devotional space underwent theoretical and practical scrutiny; ${ }^{151}$ and as the conversional ethos was broadcast in sermons and handbooks. Chavigny navigated the early phases of this process.

In Le cour nouveau, Saint-Cyran teaches his ward that Christ became incarnate to bring a new heart and a new love which are

semblable à la tendresse du cœur d'un petit enfant nouvellement formé dans le ventre de sa mere, ou né depuis peu de jours, qui à cause de sa foiblesse n'est pas capable de faire de grandes actions, ny des exercices tant soit peu penibles. [...] Il faut que cette comparaison serve de regle, \& de direction generale à une ame dans laquelle Dieu vient d'inserer ce cœur, c'est-à-dire son amour \& sa grace $[\ldots] .{ }^{152}$

similar to the tenderness of the heart in a small child recently shaped in its mother's womb or born only a few days ago, who because of its feebleness is not able to do great deeds, nor exercises that are too strenuous. $[\ldots]$ It is necessary that this comparison serve as the rule and the general direction for a soul in whom God has inserted this heart, that is, his love and his grace $[\ldots]$.

Owing to the feeble state of the new heart, a recent convert, such as Chavigny, must be his own mother and nurse and protect his soul against worldly corruption and other looming dangers. Turning inward, he must work on shaping the new heart and the new love, strengthening himself in his desire to please God. ${ }^{153}$ In order to support this process, Saint-Cyran suggests three exercises: first, to weed out from his life anything that threatens this new love; second, to meditate at least once or twice a day on the marvellous truth that all Christians form one collective Church and to this end worship in the spirit Christ and

\footnotetext{
150 Dumonceaux P., "Conversion, convertir, étude comparative d'après les lexicographes du XVII ${ }^{e}$ siècle", in Duchêne R. (ed.), La conversion au XVII e siècle (Marseille: 1983) 7-17, esp. 9-10; see also Bruun, "Prayer, Meditation, and Retreat".

151 See Papasogli B., Le "fond du coeur": figures de l'espace intérieur au XVII e siècle (Paris: 200o).

152 Saint-Cyran, Le coeur nouveau 110-114, esp. 112-113. On Saint-Cyran's strategy of conversion and its effects among, not least, the nuns of Port-Royal, see Orcibal, Les Origines II 425-427.

153 Saint-Cyran, Le coeur nouveau 114.
} 
'le corps qu'il a pris dans le ventre de la Vierge'154 ('the body he has assumed in the Virgin's womb'), and further, to wonder at the fact that he has given us this body for the Eucharistic nourishment of our souls; and third, to deploy the common means offered by the Church, that is, honouring priests, monks, churches, relics, and everything related to the worship of God, such as crucifixes, images, blessed water, rosaries, medals, and so forth. These exercises should be accompanied by little daily soul-strengthening deeds such as reading, prayer, retreat, moments of silent solitude, and a sign of affection or a service done to someone who has offended the believer. ${ }^{155}$ In this tender state, 'dans son premier âge'156 ('in his first age'), the recent convert must pay heed to three things: first, that the new heart owes everything to God and nothing to his own merit; second, that the devil sets his traps everywhere; and, third, that it is the prerogative of God to persevere in his donation of grace, and that, little by little, he separates the convert from what is illegitimate. ${ }^{157}$ All the convert can do is to dwell in a state of constant and silent supplication:

[...] il faudra lever les yeux du cœur au Ciel, \& par un simple regard diversifié en mille façons que l'amour entend, demander secours à Dieu sans dire mot, \& ne cesser jamais de l'implorer, tandis que ces ennemis nous presseront, lesquels il faut défaire en se retirant, s'il est possible, sur tout lors que le lieu \& l'occasion les favorise. ${ }^{158}$

[...] we must direct the eyes of the heart towards Heaven, and by a simple ${ }^{159}$ gaze proliferating in a thousand ways that love hears, ask for help from God without saying a word, and never cease to implore him while these enemies pressure us, whom we must undo while withdraw-

154 Ibid. 116.

155 Ibid. 115-118. The sentence is striking, given the harsh attitude towards such instruments of devotion among later Port-Royalists.

156 Ibid. 119 .

157 Ibid. 119-122.

$15^{8}$ Ibid. 122-125, esp. 125. Saint-Cyran's insistence on silent prayer accords with the instruction that the oraison mentale or even the curt and fervent oraison éjaculatoire is a more resourceful instrument than the more formulaic oraison verbale; see, on these kinds of prayer, Sales François de, Introdvction a la vie devote (Paris, l'imprimerie royale du Louvre: 1609/1619; reprint ed. 1641) 108; and D'Argentan Louis-François, Les exercices dv chrestien interievr, Où sont enseignées les pratiques pour conformer en toutes choses nostre interieure auec celuy de Iesus-Christ, \& viure de sa vie, 2 vols. (Paris, Claude Cramoisy: 1664) II 269-270.

159 The word simple means 'simple' and 'single', and Saint-Cyran generally uses it to denote a devotional demeanour divested of superfluous deeds or sentiments. 
ing, if it is possible, especially when the place and occasion are favourable for them.

In the otherwise quite terse, direct, and pragmatic instruction of Le coeur nouveau, this passage stands out. Merging several senses and forms of expression, Saint-Cyran prescribes a particular address to God: the silent prayer conveyed by the eyes of the heart. The passage brings together the notion of the eyes of the heart ${ }^{160}$ and the trusting elevated gaze of the Psalms. ${ }^{161}$ The important feature of this gaze is not that it sees, but that it trusts even when it does not see, and that it speaks from the heart while the voice is mute. It is thus a sign of directedness and trust. Saint-Cyran elaborates the notion of the simple gaze in a letter treatise from 1641, addressed to an anonymous gentleman who wishes to surrender himself to God. Here Saint-Cyran remarks that in order to draw 'cet amour du Ciel dans la terre \& du cœur de Dieu mesme [...] dans le cœur de l'homme conuerty, Dieu ne demande qu'vn simple regard interieur de cet homme, \& vne secrette inuocation'162 ('this love from heaven to earth and from the very heart of God into the heart of the converted human being, God requires nothing but a simple interior gaze of this human and a secret

160 Possibly, Saint-Cyran was influenced by the Augustinian theory of the eyes of the mind (occuli mentis) as a spiritual twin of the physical eyes; see, for this theory, Miles M., "The Eye of the Body and the Eye of the Mind in Saint Augustine's De trinitate and Confessions", The Journal of Religion 63.2 (1983) 125-142. Several Augustinian points underlined by Miles are important in this context, especially the intimate connection between the viewer and the thing which is seen spiritually; however the agency that Augustine ascribes to the soul in the spiritual vision (cf. Miles, "The Eye" 128-129), is downplayed in Saint-Cyran. Probably the wording of Ephesians 1:17-18a is an important inspiration as well: 'I pray that the God of our Lord Jesus Christ, the Father of glory, may give you a spirit of wisdom and revelation as you come to know him, so that, with the eyes of your heart enlightened, you may know what is the hope to which he has called you' (Vulgate: '[memoriam vestri faciens in orationibus meis:] ut Deus Domini nostri Jesu Christi, Pater gloriæ, det vobis spiritum sapientiæ et revelationis in agnitione ejus, illuminatos oculos cordis vestri, ut sciatis quæ sit spes vocationis ejus'). As we shall see, this passage was important for Singlin.

161 See, for example, Ps 121:1 (Ps 120:1 in the Vulgate): 'I lift up my eyes to the hills - from where will my help come'? ('Levavi oculos meos in montes, unde veniet auxilium mihi'?). This verse is one of three biblical phrases suggested by Saint-Cyran to Chavigny as a source of affection and a shield against diabolic temptations; see Le coeur nouveau 126. See also PS 123:1 (PS 122:1 in the Vulgate): 'To you I lift up my eyes, O you who are enthroned in the heavens'! ('Ad te levavi oculos meos, qui habitas in cælis'!).

162 Saint-Cyran, letter to an anon. gentleman, dated January 1641; see Letter 32, in Saint-Cyran Jean Duvergier de Hauranne, abbé de, Lettres chrestiennes et spiritvelles de messire Iean Dv Verger de Havranne, abbé de $S^{t}$ Cyran, 2 vols. (Paris, La Veuve Martin Durand - Sébastien Huré - Jean Le Mire - Rolet Le Duc: 1645-1647) II 380-461, esp. 451-452. 
invocation'). Also, the diversification that Saint-Cyran prescribes for Chavigny's simple regard reappears in other instructions. He recommends, for example, the 'oraison continuelle diuersifiée en mille manieres' ('the continuous prayer proliferating in a thousand ways') as the only remedy to purge the soul; ${ }^{163}$ and he explains how the solid devotion 'se diuersifiée en mille façons sans peine, \& souuent auec vne joye qui se renouuelle de temps en temps, sinon dans les sens, pour le moins dans le fonds de l'ame, \& de l'esprit'164 ('proliferates in a thousand ways without effort and often with a joy that renews itself little by little if not in the senses, at least at the bottom of the heart and in the spirit'). Less is more. For Saint-Cyran it is exactly the unified simplicity of the cordial gaze in its focused trust that secures its communicative abundance and thus turns this gaze into the fundamental form of supplication. There is thus for Saint-Cyran a direct connection between grace, gaze, and the convert's new heart, but we have yet to see what happens when the eye of the renewed heart is directed towards the Annunciation.

\section{Looking at the Annunciation}

At Port-Royal in the 1640s, Chavigny would have heard again the demand for a new heart and a gaze to go with it. For example, Le Maistre, a key figure in the definition of the Port-Royalist profile, declares that conversion requires

un cœur nouveau, \& non pas seulement un entendement nouveau: un cœur de feu [...]. Or ce cœur est en la seule disposition de Dieu, \& non en la notre; \& tout ce qu'un pécheur peut faire c'est d'élever les yeux vers les montagnes saintes d'où il doit descendre, \& de le demander à Dieu avec ferveur, avec gémissemens, avec assiduité. ${ }^{165}$

a new heart and not simply a new mind; a fiery heart [...]. But this heart is only at God's disposal and not at ours, and all that a sinner can do is to raise the eyes of the heart towards the saintly mountains from where it will descend, and ask God for it with fervour, with sighs, and with persistence.

163 Saint-Cyran, letter to an anon. lady, dated 20 July 1641; Letter 71, in Lettres chrestiennes I 563-588, esp. $5^{8} 7$.

164 Saint-Cyran, letter to an anon. lady, dated 18 February 1642; Letter 93, in Lettres chrestiennes I $775^{-792}$, esp. 786.

165 Undated letter from Le Maistre to D'Andilly, in Recueil de plusieurs pieces 203-206, esp. 205 . 
Le Maistre reiterates Saint-Cyran's requirement for the lifted gaze. He presents it as the token of that surrender to the trust in divine help which is the only form of agency available to the convert according to the stern Augustinianism of Port-Royal. Le Maistre's view chimed in with Antoine Singlin's preaching which funnelled a broad spectrum of Port-Royalist teaching to a dedicated audience - among them Chavigny, if we are to believe Rapin. ${ }^{166}$ Three feasts are particularly relevant in our context. The Feast of Paul's conversion inspires Singlin and his homilectic co-authors to a pedagogical exposition, as if in slowmotion, of the condensed and invisible dynamics at work in conversion; the Feast of the Annunciation prompts an exposition of Mary as a model believer; and the Feast of Epiphany occasions a representation of the Magi as the ideal viewers.

According to Singlin, Paul's conversion fleshes out the otherwise evasive work of divine grace, and therefore he invites his audience to consider

toutes les circonstances de cette Conversion. Car tout ce qui s'est fait au dehors a esté l'image de ce qui se faisoit au dedans, \& Dieu a montré visiblement dans la Conversion de ce grand Apostre, ce qu'il fait invisiblement dans celle de tous ceux qu'il attire à sa connoissance \& à son amour. ${ }^{167}$

all aspects of this conversion. For everything that happened on the outside was an image of what happened on the inside, and in the conversion of this great apostle, God showed visibly what he does invisibly in the conversion of all those whom he draws into his knowledge and his love.

Singlin reminds his audience how Christ descended from heaven, blinded Paul, and threw him to the ground. ${ }^{168}$ This blinding shows how God divests the convert of worldly insight, throwing him or her into an 'aveuglement heureux', a 'fortunate blindness', which gives access to the light of truth and life, ${ }^{169}$ but also isolates the convert from the sages of this world, turning him into a child who

166 Since Singlin was busy, the sermons were generally written by Sacy and sometimes by Antoine Arnauld at Singlin's direction as to key points and biblical passages; see Goujet Claude-Pierre, "Vie de Monsieur Singlin", in Instructions Chrétiennes sur les mystères de N. S. Et sur les principales fêtes, 5 vols. (Avignon, Aux dépens de la Societé: 1644 [=1744]) v, xxij. Josse concludes that Singlin's instructions, first published in 1671, reflect Sacy's textual rather than Singlin's oratorical work, but that their gist reappears in Singlin's letters and direction; Josse, "Introduction" 81-85.

167 Singlin, "Instruction pour le Jour de la Conversion de Saint Paul", in Instructions Chrestiennes I 702.

168 Ibid. 701.

169 Ibid. 703 . 
relies on the guidance of others. The apostle thrown to the ground teaches us that conversion must come with a complete renversement ('inversion') of our will which makes for an all-embracing renouvellement ('renewal'). ${ }^{170}$ The next step, Paul's question, 'Domine, quid me vis facere' ('Lord, what do you want me to do?') of Acts 22:10, ${ }^{171}$ shows the Apostle's readiness to obey even to the point of suffering, adopting a state of penitence, 'un changement de cœur renouvelé par une impression de grace \& d'amour'172 ('a change of heart, renewed by an imprint of grace and love'). Singlin explains that when Christ asks Paul to rise and enter the city, it is a command to enter 'dans le fond de nostre cour pour voir tout ce qui s'y passe' ('into the bottom of our heart in order to see everything that goes on there'). ${ }^{173}$ In short, the true convert remains blind to the world while contemplating God's secrets in the depths of his or her heart. ${ }^{174}$ This shedding of agency and assumption of a new and unworldly form of vision is the sine qua non of Port-Royalist conversion.

Singlin's instructions on the Annunciation add further dimensions to this vision and offer yet another model to emulate. The preacher sets the scene with verve. Mary has withdrawn into her chamber where she is occupied with secret and silent mediation on saintly matters. ${ }^{175}$ Enter Gabriel, whose greeting, 'Hail Mary, full of grace', acknowledges that she is the summit of virtue in her perfect humility. ${ }^{176}$ In her response to this angelic address, she shows herself a model recipient of divine grace as she accepts unhesitatingly the great mystery that God has chosen her to be the mother of his Son without losing her virginity, and

quoy que cette merveille parût entierement incroyable \& incomprehensible à toutes les pensées des hommes, neanmoins elle s'est contentée de se soumettre absolument à sa divine volonté, adorant les secrets de sa sagesse qu'elle ne pouvoit penetrer, \& se contentant de suivre ses ordres avec une prompte \& fidéle obéïssance. ${ }^{177}$

170 Ibid

171 Ibid. 704. Paul's retelling of his conversion in Acts 22 adds an immediate submissiveness which is absent in the first rendering of Acts 9 .

172 Ibid. 706. Singlin expands this point into a section on ecclesiastical ministry which is, however, not pertinent to our argument.

173 Singlin, "Instruction Pour le Jour de la Conversion de Saint Paul: Seconde instruction", in Instructions Chrestiennes I 710-716, esp. 714.

174 Singlin, "Instruction Pour le Jour de la Conversion de Saint Paul: II" 715.

175 Singlin Antoine, "Instruction pour l'Annonciation de la Vierge: I", in Instructions Chrestiennes II 757-766, esp. $75^{8}$.

176 Ibid. $75^{8-761 .}$

177 Ibid. 762 . 
although this marvel appeared unbelievable and incomprehensible to human thought, she nonetheless contented herself with submitting completely to the divine will behind it, worshipping the secrets of its wisdom which she could not penetrate and contenting herself with following its orders with unhesitating and faithful obedience.

The feast of the Annunciation inspires not only a celebration of Mary's docile humility and her conception of Christ, but also a meditation on the daily conception of Christ in the believer:

Car il est vray qu'il n'est né spirituellement \& corporellement tout ensemble que dans la sainte Vierge. Mais il naît encore tous les jours spirituellement dans chacun de ses membres [...]. Afin que Jesus-Christ se forme dans nous, il faut qu'il y soit conçûauparavant. ${ }^{178}$

For it is true that he is only born both spiritually and physically in the Virgin. However, he is born spiritually everyday still in his members [...]. In order that Jesus Christ be formed in us, he must first be conceived there.

In her communication with the Archangel, the Virgin 'a témoigné [...] une parfaite simplicité'179 ('demonstrated a perfect simplicity'). Singlin contrasts this simplicity with Eve's curiosity, thus underlining the sense of focus and resistance to deviation to the notion of 'simplicite' that we met in Saint-Cyran. Mary invites scrutiny, and Singlin draws on Ambrose as he states that 'des moindres gestes de son corps, qu'elles ont esté comme la figure \& le tableau de la sainteté de son ame'180 ('the slightest movements of her body were like the figure and the painting of the saintliness of her soul'). He explains this saintliness as a double disposition of 'un abbaissement continuel devant Dieu, \& un aneantissement de tout ce qu'elle estoit' ('a continuous debasement before God and an annihilation of everything that she was'), and from this first disposition emerged the second, 'un silence interieur, \& une attention à JesusChrist residant dans son sein, pour donner lieu aux operations secrettes de sa grace dans son $a m e^{181}$ ('an interior silence and an attention to Jesus Christ,

\footnotetext{
178 Ibid. 764 .

179 Singlin, "Instruction pour l'Annonciation de la Vierge: Seconde instruction", in Instructions Chrestiennes II 766-776, esp. 767 .

180 Singlin, "Instruction pour les Quatre-Temps de Noel", in Instructions Chrestiennes I 85-97, esp. 87. I have not been able to locate the Ambrose reference.

181 Ibid. 85-97, esp. 87 .
} 
lodging in her womb, [which served] to make space for the secret operations of his grace in her soul').

Singlin's third instruction on the Annunciation is dedicated to the state in which Gabriel found Mary. Withdrawal is her first quality, and again Singlin turns to Ambrose to depict her:

Elle est seule, [...] dans le secret de son cabinet, elle est seule sans aucune compagnie, \& c'est en cét etat qu'elle est saluée par l'Ange. ${ }^{182}$ [...] Puis donc que la sainte Vierge est nôtre modéle, la premiere chose que nous devons apprendre d'elle, est l'amour de la retraite. ${ }^{183}$

She is alone, $[. .$.$] in the secret of her chamber, she is alone without any com-$ pany, and it is in this state that she is greeted by the Angel. [...] Thus since the saintly Virgin is our model, the first thing that we must learn from her is the love of retreat.

Mary teaches the proper motives for retreat. Wanting to read undisturbed does not qualify: nor does the wish to avoid other people. Retreat should be prompted only by the preference for God's company over human company, ${ }^{184}$ and Singlin commands his audience to follow the Virgin's model: to withdraw from the world and to preserve in secrecy the grace that God may offer. ${ }^{185}$ Apart from solitude, the Virgin teaches believers to see the greatness of Christ behind his humble appearance and to look at worldly splendour with a sancta superbia, a saintly pride, that disregards what falsely allures and seeks instead eternal glory. This she can do because 'elle voyoit toutes choses par un œil qui ne considere point [...] les choses visibles, mais les invisibles'186 ('she saw everything with an eye that does not see [...] the visible, but the invisible things'). When believers turn this gaze towards themselves, they see that they owe everything to God and nothing to themselves: this is true humility, to 'reconnoitre que de luy-même il n'est rien, \& qu'il ne tient que de Dieu tout ce qu'il possede'187 ('recognize that they are nothing by themselves and receive

182 Singlin does not give a reference, but his translation seems to paraphrase a section from Ambrose's Expositio euangelii secundum Lucam II.

183 Singlin, "Instruction pour l'Annonciation de la Vierge: Instruction III", in Instructions Chrestiennes II 777-786, esp. 779.

184 Ibid. 780 .

185 Ibid. 781 .

186 Ibid. 782-783.

187 Ibid. 785 . The connection between humility and self-knowledge is not particular to Port-Royal, but is rehearsed here with ardent specificity. For a discussion of the role of 
only from God what they have'). All this the Virgin teaches by her model behaviour at the Annunciation, and in order to understand what this Feast is about, we have only to 'jetter les yeux sur la sainte Vierge, la considerant autant que nous pourrons comme la regle \& le modèle de nôtre vie'188 ('cast a glance at the Virgin, considering her as much as we can as the rule and the model of our life'). Singlin's invitation is not simple. He urges his audience to study the Annunciation, and while referring to the Virgin in two-dimensional terms, as image and painting, invites them to enter her body, envisaging the life that is commencing there in order to recognize it in themselves - should God bestow it. Humility is the hinge. No mere exterior attitude, humility is a deep, cognitive process that rests on knowledge of oneself as unworthy and completely dependent on divine grace.

In these instructions, Singlin offers concrete embodiments of Saint-Cyran's ideal of the renewed heart and its spiritual gaze, and the soteriological mystery that underlies it. If Paul, blinded and thrown to the ground in debasement, was the image of conversion, and Mary portrays the ideal of responsive humility in her place of retreat as she conceives the Word of God, the Magi are the model spectators. ${ }^{189}$ The Magi personify faith, for while a preacher can persuade through words and verbal responses to doubts and queries, they followed 'une étoille dans le ciel, est un objet muet, qui ne parle qu'à nos yeux, \& qui ne peut appaiser nos doutes' ('a star in the sky [which] is a silent thing that only speaks to our eyes and cannot appease our doubts'). ${ }^{190}$ While they looked at this star, however, a new light formed in their interior

qui les ait persuadez pleinement des veritez que cette étoille leur annonçoit, comme n'estant qu'un signe exterieur de la lumiere interieure

self-knowledge in seventeenth-century culture, see Moriarty M., Fallen Nature, Fallen Selves: Early Modern French Thought II (Oxford: 2006) 275-315.

188 Singlin, "Instruction pour l'Annonciation de la Vierge: Quatriéme instruction", in Instructions Chrestiennes II 786-794, esp. 786.

189 Singlin begins his instruction for Epiphany by introducing the Nativity as the beginning of all mysteries and the Epiphany as its consummation. Much as this makes sense in terms of the liturgical context, it is motivally meaningful to add the Annunciation to this constellation; see Singlin, "Pour le Jour des Rois: Premiere instruction", in Instructions chrestiennes I 261-273, esp. 261-262. See, for example, Singlin's comment that the Annunciation is the very source of the Nativity and thus the origin of all mysteries and the fulfilment of all prophesies; see Singlin, "Instruction pour l'Annonciation de la Vierge: I" 757 .

190 Singlin, "Pour le Jour des Rois: I" 263. 
\& invisible, qui a penetré le fond de leurs ames. C'est ainsi que doit estre nostre foy $[\ldots] .191$

which completely persuaded them of the truths that this star conveyed to them so that it was nothing but an exterior sign of the inner and invisible light that had penetrated the depth of their souls. This is how our faith should be $[\ldots]$.

This exterior light of the star, Singlin adds, 'n'étoit que l'image de cette autre lumiere invisible \& interieure, par laquelle il leur a ouvert les yeux du cœur, selon le langage de saint Paul, illuminatos oculos cordis vestri'192 ('was nothing but the image of this other invisible and interior light by which he opened the eyes of the heart, according to Saint Paul's words: with the eyes of your heart enlightened'). Singlin concludes this passage with a hearty encouragement to be like the Magi, 'Ne perdons point de veüe l'étoille dont il nous éclaire. Voyons les choses invisibles \& ne voyons plus les visibles'193 ('Let us not lose sight of the star with which he enlightens us. Let us see the invisible things and no longer the visible'). Having arrived before the Infant Christ, the Magi show the ideal form of worship, silent and humble: 'Ils ne luy parlent que du cœur qui est la langue de Dieu'194 ('They only spoke to him with their heart which is the tongue of God'). The Magi's prostration (cf. Mt 2:11) signifies their humble imitation of the humble appearance of the Infant, ${ }^{195}$ and all the believer can do is signified in their three-fold offering: the gold of external qualities, the incense of the elevation of the soul toward God, and the myrrh of mortification and penitence. ${ }^{196}$

We cannot know whether Chavigny brought home the lesson and, in his chapel at the Hôtel de Chavigny, complied with Singlin's instruction to study, in the insightful manner of the Magi, the model of his own renewal in the humility of the Virgin. We cannot know whether, looking at his painting, he contemplated the possibility that God in his infinite grace might bestow upon him conversion and make him conceive Christ spiritually, or whether he was inspired to silent prayer of the heart by the sight of Mary's encounter with

\footnotetext{
191 Ibid. 264.

192 Singlin, "Pour le Jour des Rois: Troisième instruction", in Instructions Chrestiennes I 287297, esp. 289, with reference to Eph 1:18.

193 Singlin, "Pour le Jour des Rois: I" 267.

194 Singlin, "Pour le Jour des Rois: Seconde instruction", in Instructions Chrestiennes I 274-287, esp. 285 .

195 Singlin, "Pour le Jour des Rois: III" 296.

196 Singlin, "Pour le Jour des Rois: II" 285-286.
} 
Gabriel. Any of Champaigne's three Annunciations identified as the painting from the Hôtel de Chavigny could have supported such messages. They could have offered to Chavigny a mirror of what he ought to be and, indeed, what the mystery of the Incarnation might enable him to be. Whichever picture it was, the sheer motif of the Annunciation would have served to represent the ideal devout in her retreat, alone with God's messenger, communicating intensely with words, with gestures, and in silence, thus personifying the silent prayer that was prescribed by Saint-Cyran in Le cour nouveau and by Singlin in his instructions.

\section{The Private Chapel Revisited}

This contemplation would have been framed by Chavigny's chapel. Was it a locus of prayer, a locus of retreat, and a locus of intensified communication with God - or a cramped stage for lightweight devotion? Did he associate his private oratory with the Virgin's chamber, as suggested by Suffren? Did he forge a particularly strong bond between the Virgin and his domestic space, as suggested by modern scholars? As we have seen, the Annunciation and the Nativity were favourite motifs in grand-siècle private oratories. ${ }^{197}$ Scholars have suggested that paintings of the Annunciation located in a domestic setting such as Mary's chamber were particularly fitting for a private chapel. Based on her study of the new domestic iconography emerging in Annunciations of fifteenth-century Netherlands, Nuechterlein finds that the domestic context turns Mary into 'a pious housewife, reading quietly at home when Gabriel appears to her'. 198 Closer to our chronological focus, Garnot points to the presence of a fireplace with a nestling cat as elements of a familiarly domestic

197 Gonçalves even argues that it would be surprising to see an Annunciation in a parish church; see Gonçalves, Philippe de Champaigne cat. 3, 15. See, however, the list of Annunciations in parish churches of Le Mans, in Ménard, Une histoire 190-195.

198 Nuechterlein J., "The Domesticity of Sacred space in the Fifteenth-Century Netherlands", in Hamilton S. - Spicer A. (eds.), Defining the Holy: Sacred Space in Medieval and Early Modern Europe (Farnham: 2006) 49-79 (55); see also LeZotte A., "Mary Magdalene and the Iconography of Domesticity", in Erhardt M. A. - Morris A. M. (eds.), Mary Magdalene, Iconographic Studies from the Middle Ages to the Baroque (Leiden: 2012) 383-397, esp. 385396. Reindert Falkenburg, in his fresh look at Panofsky's iconographical reading of the various fifteenth-century Annunciations, shows how, when viewed against the backdrop of contemporary devotional literature, the domestic utensils and everyday artifacts displayed in Campin's Merode Triptych encourages the viewer to prepare her soul for Christ's entry; see Falkenburg, "The Household of the Soul: Conformity in the Merode Triptych", in Ainsworth M. (ed.), Early Netherlandish Painting at the Crossroads: A Critical Look at 
character, in his argument that the Montrésor Annunciation best fits within the alleged intimacy of Chavigny's private chapel. ${ }^{199}$

However, this domestic perspective does not seem applicable to the Hôtel de Chavigny; nor, I suggest, to seventeenth-century private oratories more generally. On the one hand, the grand-siècle Mary is not domestic. Indeed, one of her key features is the power to convert, if need be, with force; and the early modern Mary has a militant streak that accords with her victorious association with the Battle of Lepanto (1571) and with patronage of campaigns waged against heretics and unbelievers. ${ }^{200}$ Her attributes are not primarily those of home and family, and it is her exemplary chastity and humility that are presented as models of imitation for individual men and women. On the other hand, as we have seen, the private oratory or chapel is, ideally, not quite domestic either. Conflation of the chapel and the rest of the house is considered an abuse, and the candlesticks, vases, cushions, and other paraphernalia mentioned in inventories for private chapels, ${ }^{201}$ rather than fostering an impression of 'homeliness', are remedies to sustain and enforce devotional concentration. ${ }^{202}$

Current Methodologies (New York: 2001) 2-17. See also the discussion of Falkenburg in LeZotte, "Mary Magdalene" 385-386.

199 Garnot, "Philippe de Champaigne" 399. On the increasing importance of the setting of Annunciation scenes from the fourteenth century onward, see Robb D. M., "The Iconography of the Annunciation in the Fourteenth and Fifteenth Centuries", The Art Bulletin 18.4 (1936) 480-526 (485). Compared to late medieval antecedents, Champaigne generally reduces the furnishings of Mary's chamber to a bare minimum.

200 To mention but two grand-siècle examples, the Jesuit François Poiré describes the Virgin as a determined champion against all forms of heresy, from Arius and the Albigensians, to Luther, Zwingli, and Calvin; see Poiré, La triple covronne de la bien-hevrevse vierge Mere de Diev (Paris, Sébastien Cramoisy - Gabriel Cramoisy: 1630; reprint ed. 1656) 400-401. Cf. Condren's prayer of greeting composed for Marian feasts: 'Rejoüissez-vous Marie, toûjours Vierge! Parce que vous avez détruit, vous seule, toute les heresies dans tout le monde' ('Hail be to you, Mary, ever Virgin! Because you have destroyed all heresies in the whole world'); see Condren Charles de, Saintes instructions pour la conduite de la vie chrestienne, dressées pour une personne de grande qualité (Paris, M. Le Petit: 1671) 343. For more examples, see Bruun M. B. - Havsteen S. R. - Nagelsmit E. - Mejrup K. - Nørgaard L., "A Marvellous Model of Female Conduct: Judith in Seventeenth-Century France", Transfiguration 2014 (publ. 2018) 9-64, esp. 23-28.

201 See, for example, the inventory for Mme de Guise's chapel in her palace in Alençon, ADo, inv. H 192. I owe a debt of thanks to Eelco Nagelsmit for his insights regarding this inventory. See also the description of chapel furnishings in Hillman, Female Piety 87-91.

202 See Laven M., "Devotional Objects", in Avery V. - Calarescu M. - Laven M. (eds.), Treasured Possessions: From the Renaissance to the Enlightenment (Cambridge: 2015) 239-244; and Fairchilds C., "Marketing the Counter-Reformation: Religious Objects and Consumerism in Early Modern France", in Adams C. - Censer J. R. - Graham L. J. (eds.), Visions and Revisions of Eighteenth-Century France (University Park: 1997) 31-58. 
I would instead argue that the close connection, even resemblance, between representations of the Annunciation and the private oratory resonates with the ideal of retreat that was so central to grand-siècle devotion, and which, as Singlin reminds us, produced, in the sense of framing and fashioning, the convert.

A Private Mystery: Concluding Remarks

When Chavigny commissioned Champaigne to paint an Annunciation for his new chapel, he abided by social codes and familial patterns. These were norms pertaining to patronage, trends, and appearance, but they were also tinged by the call for sincere conversion, retreat from the world, and deep contemplation of humility and divine grace. Chavigny's directors encouraged the count and his peers to see the Annunciation as a representation not only of the mystery of the Incarnation, but also of the mystery of conversion, and Champaigne's visual image thus set before Chavigny's physical and spiritual eyes the contours of a radical, but intangible challenge. It showed the incarnational meeting between Heaven and Earth; it staged Mary's chamber as the locus of withdrawal and communication with God; it portrayed her, in her radical humility and her conception of Christ, as a figure of identification; and it hinted at the embryonic shape of the new heart of a convert.

The example of Chavigny reveals a system of devotional zones, established across a broad array of materials, media, and genres: the Hôtel de Chavigny, its chapel, Champaigne's Annunciation, the Virgin's womb, and the new heart conceived in the convert, are on a continuum and yet are distinct devotional spaces. On the horizon hover the court, the Château de Chavigny, and PortRoyal, as well as other religious institutions. These zones, which we have seen to revolve around the Annunciation at the Hôtel de Chavigny, constitute a micro-cosmos of their own, but they also exemplify the devotional temper of mid-seventeenth century France and the more or less explicitly material, spatial, and spiritual circumstances that embed grand-siécle representations of the mysteries of faith. Centering on the elusive figure of Léon Bouthillier, Comte de Chavigny, who navigated these zones - perhaps with fluctuating success - this example, for all its open questions, yields a glimpse of the grand-siècle believer, spurred on by political ambition, disciplined by zealous directors, and scrutinized by various and sundry observers. Chavigny possibly epitomizes the gaze that devotional instructors taught their protégés to apply when considering the mystery of the Annunciation - a gaze expressive of faith, that shuns the visible in favour of the invisible, that strives for self-annihilation 
and acknowledges the need for God's grace, and that converts spiritual insight into silent prayer. Perhaps Champaigne's Annunciation for Chavigny's chapel at the Hôtel de Chavigny helped to shape this gaze.

\section{Bibliography}

\section{Sources}

Arnauld Angélique, Lettres de la Reverend Mere Marie Angelique Arnauld: abbesse et reformatrice, 3 vols. (Utrecht, Aux Depens de la Compagnie: 1742-1744).

Arnauld Henri, Statuts du diocese d'Angers (Angers, Olivier Avril: 1680).

Barry Paul de, Les Meditations de Philagie, povr tovs les iovrs de l'année, 2 vols. (Lyon, Philip. Bordes - Laurent Arnaud - Cl. Rigaud: 1649).

Boileau Jean-Jacques, "Avertissement", in Liancourt Jeanne de Schomberg, duchesse de, Reglement donné par une dame de haute qualité a $M^{* * *}$ sa petite-fille Pour sa Conduite, \& pour celle de sa Maison, avec un autre Reglement que cette Dame avoit dressé pour elle-mesme (Paris, Augustin Leguerrier: 1698) 1-101.

Brienne L.-H. de Loménie, comte de, Mémoires inédits de Louis-Henri de Loménie, comte de Brienne, secrétaire d'état sous Louis XIV publiés sur les Manuscrits autographs, ed. F. Barrière, 2 vols. (Paris and Leipzig: 1828).

Canones et decreta sacrosancti oecuminici Concilii Tridentini (Rome: 1834; reprint ed., Leipzig: 1866).

Condren Charles de, Saintes instructions pour la conduite de la vie chrestienne, dressées pour une personne de grande qualité (Paris, M. Le Petit: 1671).

D'Andilly Robert Arnauld, Lettres de Monsievr Arnavld d'Andilly (Paris, La veuve Jean Camusat - Pierre le Petit: 1645).

D'Andilly R. A., Arnauld d'Andilly Défenseur de Port-Royal (1654-1659): sa correspondence inédite avec la Cour, ed. P. Jansen (Paris: 1973).

D’Andilly R. A., Mémoires, suivis de Antoine Arnauld, dit l'abbé Arnauld: Mémoires, ed. R. Pouzet (Paris: 2008).

D'Argentan Louis-François, Les exercices dv chrestien interievr, Où sont enseignées les pratiques pour conformer en toutes choses nostre interieure auec celuy de Iesus-Christ, \& viure de sa vie, 2 vols. (Paris, Claude Cramoisy: 1664).

D’Argenville Antoine Joseph Dezallier, Abrégé de la vie des plus fameux peintres, avec leurs portraits gravés en taille-douce, les indications de leurs principaux ouvrages, 3 vols. (Paris, de Bure l'Aîné: 1745).

David Claude, Oraison funebre de tres-haute et tres-puissante Princesse Marie-Therese d'Autriche, Reyne de France et de Navarre (Paris, Edme Couterot: 1684). 
Démia Charles, Tresor clerical ou Conduites pour acquerir et conserver la Sainteté Ecclesiastique, recueilli des Autheurs les plus considerables de ce temps, qui ont traité de ces matieres (Lyon, Jean Certe: 1682).

Faillon E.-M. (ed.), Vie de M. Olier, fondateur du séminaire de S. Sulpice, 2 vols. (Paris: 1853).

Félibien André, Entretiens sur les vies et sur les ouvrages des plus excellens peintres anciens et modernes, cinquième partie (Paris, Sébastien Mabre-Cramoisy: 1688).

Fléchier Esprit, Oraison funebre de Marie Terese d'Autriche, Infante d'Espagne, Reine de France et de Navarre (Paris, Sébastien Mabre-Cramoisy: 1684).

Fontaine Nicolas, Mémoires pour server a l'histoire de Port-Royal, 2 vols. (Utrecht, Aux dépens de la Compagnie: 1736).

Fromentières Jean-Louis de, Oraison funebre d'Anne d'Autriche infante d'Espagne, Reine de France, et mere du Roi (Paris, Sébastien Mabre-Cramoisy: 1666).

Godeau Antoine, Ordonnances et instructions synodales (Paris, Jean Camusat - Pierre le Petit: 1644).

Goujet Claude-Pierre, "Vie de Monsieur Singlin”, in Instructions Chrétiennes sur les mystères De N. S. Et sur Les principales fêtes où sont expliquées les Epîtres \& Evangiles des Dimanches de l'année, vol. 5 (Avignon, Aux dépens de la Societé: 1644 [=1744]).

Grillié Nicolas, Oraison funebre prononcee dans l'Eglise des Avgvstins de Paris [...] pour les Tres-Chrestien Roy de France \& de Nauarre, LOVYS LE IVSTE (Paris, Vuefue Martin Durand: 1643).

Hermant G., Mémoires (1630-1663), ed. A. Gazier, 6 vols. (Paris: 1905-1910).

Histoire de l'origine des penitens et solitaires de Port-Royal des champs (Mons, Migeot le fils: 1733).

Joly Claude, Les devoirs dv chrestien dresses en forme de catechisme [...] en favevr des cvrez \& des Fidelles de son Diocese (Paris, Pierre le Petit: ${ }^{6}{ }_{1677}$ ).

La Croix Claude de, Le parfaict ecclesiastiqve ov Diverses instrvctions sur toutes les fonctions Clericales (Paris, Pierre de Bresche: 1666).

Lancelot Claude, Mémoires touchant la vie de Monsieur de S. Cyran, 2 vols. (Cologne, La Compagnie: 1738 ).

Le Camus Étienne, Ordonnances synodales dv diocese de Grenoble (Grenoble - Lyon, Alexandre Giroud - Claude Rey: 169o).

Le Maistre Antoine, "Memoire de M. le Maitre touchant les personnes que Dieu auoit touchées d'un sentiment de pénitence \& qui s'étoient retirées en divers tems dans l'ancienne Abbaye de Port-Royal des champs", in Fontaine Nicolas, Mémoires pour server a l'histoire de Port-Royal, 2 vols. (Utrecht, Aux dépens de la Compagnie: 1736) I $\mathrm{i}-\mathrm{x}$.

Le Moyne Pierre, Dévotion aisée (Paris, Antoine de Sommaville: 1652). 
Liancourt Jeanne de Schomberg duchesse de, Reglement donné par une dame de haute qualité a $M^{* * *}$ sa petite-fille Pour sa Conduite, \& pour celle de sa Maison, avec un autre Reglement que cette Dame avoit dressé pour elle-mesme (Paris, Augustin Leguerrier: 1698).

Louis P.-Y. (ed.), François Mansart: les bâtiments: Marchés de travaux (1623-1665) (Paris: 1998).

Motteville F. B. de, Mémoires de Mme de Motteville, nouvelle édition, ed. M. F. Rieaux, 4 vols. (Paris: 1896).

Noulleau Jean-Baptiste, Le grand Homme d'Estat selon toutes les maximes de la politique chrétienne, la seule vraie politique du monde (Rennes, J. Durand: 1653).

Pascal B., Les Provinciales, ed. L. Cognet (Paris: 1965).

Pascal J., Règlement pour les enfants in Blaise Pascal: OEuvres complètes, ed. J. Mesnard, 4 vols. (Paris: 1991).

Pinthereau François, Le Progrez dv Ianssenisme descovvert, a Monseignevr le Chancelier par le sievr de Preville (Avignon, Pierre Thomas: 1655).

Rancé A.-J. Bouthillier de, Correspondance, ed. A.-J. Krailsheimer, 4 vols. (Paris Cîteaux: 1993).

Rapin R., Mémoires du P. René Rapin de la compagnie de Jésus sur l'église, la ville et le jansénisme, ed. L. Aubineau, 3 vols. (Paris: 1865).

Recueil de plusieurs pieces pour servir a l'histoire de Port-Royal (Utrecht, Aux Dépens de la Compagnie: 1740).

Renaudot Théophraste, Recveil de tovtes les novvelles Ordinaires, Extraordinaires, Gazettes \& autres Relations (Paris, Au Bureau d'Adresse: 1637).

Retz Jean-François Paul de Gondi Cardinal de, Les Contre temps du Sieur de Chavigny, premier ministre de M. le Prince (s.l., 1652).

Richard Jean, Pratiques de pieté pour honorer le S. Sacrement, tirées de la Doctrine des Conciles \& des Saints Peres (Cologne, Balthasar d'Egmond: 1683).

Rouvroy Saint-Simon L. de, Mémoires, ed. Y. Coirault, 8 vols. (Paris: 1983-1988).

Saint Georges G. de, Mémoires inédits sur la vie et les ouvrages des membres de l'Académie royale de peinture et de sculpture, ed. L. Dussieux - E. Soulié - Ph. De Chennevières P. Mantz - A. de Montaiglon, 2 vols. (Paris: 1854).

Saint-Cyran Jean Duvergier de Hauranne, abbé de, "Le coeur nouveau, ov exercice pour une personne engagée dans le monde, \& dans le mariage, nouvellement convertie à Dieu", in Theologie familiere avec divers autres petits traitez de Devotion (Paris, la Veuve Jean Le Myre: 1643; reprint ed., 1669) 109-128.

Saint-Cyran Jean Duvergier de Hauranne, abbé de, Lettres chrestiennes et spiritvelles de messire Iean Dv Verger de Havranne, abbé de $S^{t}$ Cyran, 2 vols. (Paris, La Veuve Martin Durand - Sébastien Huré - Jean Le Mire - Rolet Le Duc: 1645-1647).

Sainte-Beuve C.-A., Port-Royal, 5 vols. (Paris: 1840-1859). 
Sales François de, Introdvction a la vie devote (Paris, l'imprimerie royale du Louvre: 1609/1619; reprint ed. 1641).

Sales François de, Traicté de l'amovr de Diev (Lyon, Pierre Rigaud: 1616; reprint ed. 1617). Singlin Antoine, Instructions chrestiennes sur les mysteres de Nostre Seigneur JésusChrist et sur les principales festes de l'année, 5 vols. (Paris, A. Pralard: 1692).

Singlin A., Lettres d'Antoine Singlin, ed. A.-C. Josse (Paris: 2004).

Suffren Jean, Advis et exercises spiritvels pour bien employer les iours, les semaines, les mois \& les années de la vie (Paris, Claude Sonnius - Denis Bechet: 1642; reprint ed. 1646).

Suffren Jean, L'Annee Chrestienne, Ov Le Sainct et Profitable employ du temps pour gaigner l'Éternité, 4 vols. (Paris, Claude Sonnius and Denis Bechet: 1640-1641; reprint ed.1642).

\section{Research Literature}

Allden M. - Beresford R., "Two Altar-Pieces by Philippe de Champaigne: Their History and Technique", The Burlington Magazine 131.1035 (1989) 395-406.

Ayers A., The Architecture of Paris: An Architectural Guide (Stuttgart - London: 2004).

Belin C., La conversation intérieure: la méditation en France au xviie siècle (Paris: 2002) 99-111.

Bergin J., Cardinal Richelieu: Power and the Pursuit of Wealth (New Haven - London: 1985).

Bertrand A., Art and Politics in Counter-Reformation Paris: The Case of Philippe de Champaigne and his patrons (1621-1674), Ph.D. dissertation (University of Pittsburgh: 2001).

Beugnot B., "Loisir, retraite, solitude", in Fumaroli M. - Salazar P.-J. - Bury E. (eds.), Le loisir lettré à l'âge classique (Geneva: 1996) 173-195.

Boer W. de, "Invisible Contemplation: A paradox in the Spiritual Exercises", in Enenkel K. - Melion W. S. (eds.), Meditatio - Refashioning the Self: Theory and Practice in Late Medieval and Early Modern Intellectual Culture, Intersections 17 (Leiden: 2010) $235^{-256 .}$

Boer W. de - Enenkel K. - Melion W. S. (eds.), Jesuit Image Theory, Intersections 45 (Leiden - Boston: 2016).

Braham A. - Smith P., "François Mansart's Work at the Hôtel de Chavigny", Gazette des Beaux-Arts 66.2 (1965) 317-330.

Braham A. - Smith P., François Mansart, 2 vols. (London: 1973).

Bruun M. B. - Havsteen S. R. - Nagelsmit E. - Mejrup K. - Nørgaard L., "A Marvellous Model of female Conduct: Judith in Seventeenth-Century France", Transfiguration 2014 (publ. 2018) 9-64. 
Bruun M. B. - Nørgaard L. - Nagelsmit E. - Havsteen S. R. - Mejrup K., "Withdrawn amidst the World: Rancé's Conduite chrétienne for Mme de Guise (1697)”, Early Modern French Studies 39.1 (2017) 57-74.

Bruun M. B., "A Solitude of Permeable Boundaries: The Abbey of La Trappe between Isolation and Engagement", in Göttler C. - Enenkel K. (eds.), Solitudo: Spaces, Places, and Times of Solitude in Late Medieval and Early Modern Europe, Intersections 56 (Leiden - Boston: 2018) 451-479.

Bruun M. B., "Prayer, Meditation, and Retreat", in Lyons J. D. (ed.), The Oxford Handbook of the Baroque (Oxford: 2018).

Bruun M. B., "Time Well Spent: Scheduling Private Devotion in Early Modern France", in Maber R. - Barker J. (eds.), Managing Time: Literature and Devotion in Early Modern France (Oxford: 2017) 35-68.

Cojannot-Le Blanc M., "La foi et les œuvres: Postface sur l'œuvre peint de Philippe de Champaigne et ses possibles liens avec la spritualité de Port-Royal", in Cojannot-Le Blanc M. (ed.), Philippe de Champaigne ou la figure du peintre janséniste (Paris: 2011) 171-216.

Cousinié F., "The Mental Image in Representation: Jean Aumont, L'Ouverture intérieure du royaume de l'Agneau occis dans nos cours (166o)", in Melion W. - Dekoninck R. Guiderdoni-Bruslé A. (eds.), Ut pictura meditatio: The Meditative Image in Northern Art, 1500-1700 (Turnhout: 2012) 203-246.

Dorival B., "Les oeuvres de Philippe de Champaigne sur le subjet de l'Annonciation", Bulletin de la société de l'histoire de l'Art Français 1970 (publ. 1972) 45-71.

Dorival B., Philippe de Champaigne 1602-1674, 2 vols. (Paris: 1976).

Dumonceaux P., "Conversion, convertir, étude comparative d'après les lexicographes du XVII e siècle", in Duchêne R. (ed.), La conversion au XVII ${ }^{e}$ siècle (Marseille: 1983) 7-17.

Fairchilds C., "Marketing the Counter-Reformation: Religious Objects and Consumerism in Early Modern France", in Adams C. - Censer J. R. - Graham L. J. (eds.), Visions and Revisions of Eighteenth-Century France (University Park: 1997) $31-58$.

Falkenburg R., "The Household of the Soul: Conformity in the Merode Triptych", in Ainsworth M. (ed.), Early Netherlandish Painting at the Crossroads: A Critical Look at Current Methodologies (New York: 2001) 2-17.

Gady A., Les hôtels particuliers de Paris: du Moyen âge à la Belle époque (Paris: 2008). Garnot N. S. F., "L'Annonciation, vers 1642", in Tapié A. - Garnot N. S. F. et al., Philippe de Champaigne (1602-1674) entre politique et dévotion (Paris: 2007) 129-131.

Garnot N. S. F., "Philippe de Champaigne et ses commanditaires", in Boyer J.-C. Gaehtgens B. - Gady B. (eds.), Richelieu patron des arts (Paris: 2009) 395-406.

Goldmann L., Le Dieu caché: étude sur la vision tragique dans les Pensées de Pascal et dans le théâtre de Racine (Paris: 1959; reprint ed., 1975). 
Gonçalves J., Philippe de Champaigne: La vie, l'ouvre et le catalogue en cinq livres [...]. Catalogue des peintures, dessins et désattributions Nouvelle édition revue et corrigée (April 2013 [2008]) http://www.josegoncalves.fr/tronc/PdC-catalogue-2013 -fusionn\% $3 \%$ A9.pdf (21.05.2018).

Gonçalves J., Philippe de Champaigne: le patriarche de la peinture (Paris: 1995).

Hillman J., Female Piety and the Catholic Reformation in France (Abingdon: 2014).

Ingamells J., The Wallace Collection: Catalogue of Pictures III:French before 1815 (London: 1989).

Josse A.-C., "Introduction", in Josse A.-C. (ed.), Lettres d'Antoine Singlin (Paris: 2004) 9-145.

Krüger K., "Mute Mysteries of the Divine Logos: On the Pictorial Poetics of Incarnation", in Melion W. - Wandel L. P. (eds.), Image and Incarnation in Early Modern Doctrine of the Pictorial Image, Intersections 39 (Leiden - Boston: 2015) 76-108.

Laven M., "Devotional Objects”, in Avery V. - Calarescu M. - Laven M. (eds.), Treasured Possessions: From the Renaissance to the Enlightenment (Cambridge: 2015) 239-244.

Le Guillou Y., Les Bouthillier, de l'avocat au surintendant (ca 1540-1652): histoire d'une ascension sociale et formation d'une fortune, Thèse pour le diplôme d'archiviste paléographe (École nationale des chartes, 1997).

Lesaulnier J., "Chavigny, Léon Bouthillier, comte de", in Lesaulnier J. - McKenna A. (eds.), Dictionnaire de Port-Royal (Paris: 2004) 256-258.

Lesaulnier J., "Philippe de Champaigne et Port-Royal: Les leçons d'une correspondance", in Cojannot-Le Blanc M. (ed.), Philippe de Champaigne ou la figure du peintre janséniste (Paris: 2011) 13-29.

LeZotte A., "Defining Domestic: An Examination of the Characteristics and Function of the Home Setting in Early Netherlandish Paintings", The Journal of Architecture, Design and Domestic Space 6.1 (2009) 5-17.

LeZotte A., "Mary Magdalene and the Iconography of Domesticity", in Erhardt M. A. Morris A. M. (eds.), Mary Magdalene, Iconographic Studies from the Middle Ages to the Baroque (Leiden: 2012) 383-397.

Lyons J. D., Before Imagination: Embodied Thought from Montaigne to Rousseau (Palo Alto: 2005).

Marin L., "Signe et représentation: Philippe de Champaigne et Port-Royal", Annales 25.1 (1970) 1-29.

Marin L., Philippe de Champaigne: Ou la présence cachée (Paris: 1995).

Martin É. M., Port-Royal Aesthetics, Ph.D. dissertation (Princeton University: 2006).

Mayer D., "Madame du Plessis-Guénégaud, née Elisabeth de Choiseul (1610-1677) I-II", XVII ${ }^{e}$ siècle 155 (1987) 173-186; $15^{6}$ (1987) 313-327.

McCormack J. W., "Discerning Tears in Early Modern Catholicism”, in Aydelotte L. (ed.), A Mirror for Medieval Early Modern Studies (Chicago: 2010) 49-59. 
Melion W. S., "Meditative Images and the Portrayal of Image-Based Meditation", in Melion W.S. - Dekoninck R. - Guiderdoni-Bruslé A. (eds.), Ut pictura meditatio: The Meditative Image in Northern Art, 1500-1700 (Turnhout: 2012) 1-60.

Mérot A., Eustache Le Sueur (1616-1655) (Paris: 1987).

Mérot A., Retraites mondaines: Aspects de la décoration intérieure à Paris, au xviie siècle (Paris: 1990).

Mignot C., 'Le château de Pont en Champagne, la 'maison aux champs' de Claude Bouthillier, surintendant des finances de Louis XIII", Monuments et mémoires de la Fondation Eugène Piot 84 (2005) 173-212.

Miles M., "The Eye of the Body and the Eye of the Mind in Saint Augustine's De trinitate and Confessions", The Journal of Religion 63.2 (1983) 125-142.

Moriarty M., Fallen nature, fallen selves: Early modern French thought II (Oxford: 2006).

Mousnier R., Les Institutions de France sous la monarchie absolue, 1598-1789, 2 vols. (Paris: 1974-1980).

Neveu B., "Un ami de Port-Royal: Guillaume Du Gué de Bagnols (1616-1657)", Chroniques de Port-Royal: bulletin de la Société des amis de Port-Royal 15-16 (1966) 45-92.

Neveu B., Sébastien-Joseph du Cambout de Pontchâteau (Paris: 1969).

Nuechterlein J., "The Domesticity of Sacred space in the Fifteenth-Century Netherlands", in Hamilton S. - Spicer A. (eds.), Defining the Holy: Sacred Space in Medieval and Early Modern Europe (Farnham: 2006) 49-79.

Orcibal J., Les Origines du Jansénisme, vol. 2: Jean Duvergier de Hauranne: Abbé de SaintCyran et son Temps (Louvain and Paris: 1947).

Orcibal J., Les Origines du Jansénisme, vol. 3:Jean Duvergier de Hauranne: Abbé de SaintCyran et son Temps: Appendices, bibliographie et tables (Paris: 1948).

Orcibal J., Les Origines du Jansénisme, vol. 5: La spiritualité de Saint-Cyran (Paris: 1962).

Orcibal J., Saint-Cyran et le jansénisme (Paris: 1961).

Papasogli B., Le "fond du cour": figures de l'espace intérieur au XVII' siècle (Paris: 2000). Pericolo L., Philippe de Champaigne: "Philippe, homme sage et vertueux". Essai sur l'art et l'oeuvre de Philippe de Champaigne (1602-1674) (Tournai - Bruxelles: 2002).

Quantin J.-L., "Augustinisme, sexualité et direction de conscience: Port-Royal devant les tentations du duc de Luynes", Revue de l'histoire des religions 220.2 (2003) 167-207.

Quantin J.-L., "Port-Royal et la haute noblesse: sur le cas du duc de Luynes (1620169o)", in Grell C. - Ramière de Fortanier A. (eds.), Le second ordre: I'idéal nobiliaire. Hommage à Ellery Schalk (Paris: 1999) 109-131.

Ranum O., Richelieu and the Councillors of Louis XIII: A Study of the Secretaries of State and Superintendents of Finance in the Ministry of Richelieu 1635-1642 (Oxford: 1963). Régent-Susini A., Le Marbre et la Cendre. L'orais on funèbre 1643-1715 (Paris: forthcoming). Robb D. M., "The Iconography of the Annunciation in the Fourteenth and Fifteenth Centuries", The Art Bulletin 18.4 (1936) 480-526.

Ross L., Medieval Art: A Topical Dictionary (Westport- London: 1996). 
Rubin M., Mother of God (New Haven - London: 2007).

Scott P., Le Gouvernement présent, ou éloge de son Eminence, satyre ou la Miliade (London: 2010).

Tapié A. - Garnot N. S. F. et al., Philippe de Champaigne (1602-1674) entre politique et dévotion (Paris: 2007).

Tapié A. - Garnot N. S. F., "Dialogues avec Port-Royal: une pensée picturale (16461662)", in Tapié A. - Garnot N. S. F. (eds.), Philippe de Champaigne (1602-1674) entre politique et dévotion (Paris: 2007) 147-217.

Waller G., A Cultural Study of Mary and the Annunciation:From Luke to the Enlightenment (London - New York: 2015).

Webb D., "Domestic Space and Devotion in the Middle Ages", in Hamilton S. Spicer A. (eds.), Defining the Holy: Sacred Space in Medieval and Early Modern Europe (Farnham: 2006) 27-47. 